\title{
PRACTICAL HINTS TO SCIENTIFIC TRAVELLERS
}

EDITED BY

H.A.BROUWER

และ

VOLUME II 
NUNC COGNOSCO EX PARTE

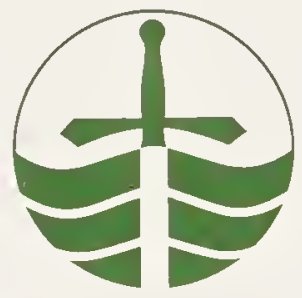

TRENT UNIVERSITY LIBRARY

PRESENTED BY

Mr. G.M. Douglas 

Digitized by the Internet Archive in 2019 with funding from Kahle/Austin Foundation 


\title{
PRACTICAL HINTS TO \\ SCIENTIFIC TRAVELLERS
}

EDITED BY

\author{
H. A. BROUWER \\ Profissor of Geology, Delft \\ I
}

SECOND, REVISED EDITION

WITH ILLUSTRATIONS

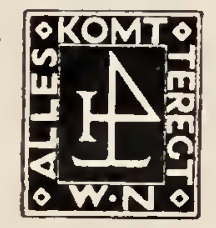

THE HAGUE

MARTINUS NIJHOFF

1925 
Q $116.587 \quad .1$ 
PRACTICAL HINTS TO SCIENTIFIC TRAVELLERS 
All rights reserved

Printed in Holland 


\section{PREFACE}

The principal object of this book is to compile the experiences of scientific explorers in different countries, so that these experiences are easily accessible. It is not the intention to compete with the existing manuals which have in view to furnish the traveller with a compendium of scientfic learning.

Many travellers, although well equipped with regard to scientific work, are only poorly informed as to the things of everyday life as well as to the customs and manners which prevail among white and colored peoples in distant regions. Yet this knowledge is hardly less necessary for the success of a journey.

Personal qualities and personal tastes play an important part in the treatment of some of the subjects. The attentive reader will encounter no difficulties in selecting these subjects, and he may follow the advice or not.

Delft (Holland), September 1925.

H. A. Brouwer 



\section{CONTENTS}

Preface

The Netherlands East Indies, by H. A. Brouwer and N. Wing EAston... . . . . . . . 1

South- and East-Africa, by Percy A. WAGner and Tudor G. Trevor . . . . . . . . . . 39

The Philippines, by WArren D. Sirth . . . 99 



\section{PRACTICAL HINTS TO EXPLORERS IN THE NETHERLANDS EAST INDIES}

\section{BY}

DR. H. A. BROUWER M. E.

Professor of Geology at the Technical University of Delft.

and

N. WING EASTON M. E.

Formerly Chief Engineer in the Netherlands Indian Mining Department, ex.Managing-Director of the Dordt-Oil-Company.

Hints $I$ 



\section{PRACTICAL HINTS TO EXPLORERS IN THE NETHERLANDS EAST INDIES}

BY

H. A. BROUWER and N. WING EASTON ${ }^{1}$ )

\section{PREPARATORY MATTER}

Though every scientific explorer may be supposed to be acquainted with the persons or institutions whence he can gather information about the details of his specialty, it seems desirable to give some general indications. There are various societies and institutions whose special object is the scientific exploration of the Dutch Indies, or the furthering of this ideal in one way or another. These are very willing to oblige the traveller with information.

\section{$A$. institutions in the NetHerLands:}

1. Maatschappij ter bevordering van het Natuurkundig Onderzoek der Nederlandsche Koloniën (Society for the Furtherance of physical Research in the

1) With the collaboration of W. van Bemmelen, and H. Witkamp. A paper dealing with the same subject is: W. Volz, Ausriistung und Reise praxis, Erfahrungen auf Forschungsreisen in Niederländisch-Ost-Indien, Tijdschr. Kion. Ned. Aardrijksk. Gen. XXVIII, 1911, p. 247-278. 
Neth. Colonies) at Amsterdam; - Hon. Secretary (at present) Prof. Dr. H. F. Nierstrasz, Utrecht.

2. Vereeniging Koloniaal Instituut (Society Colonial Institute) at Amsterdam.

3. Indisch Genootschap (Indian Society) at the Hague; - 14 v. Galenstraat.

4. Koninklijk Instituut voor Taal-, Land- en Volkenkunde van Nederlandsch Indië (Royal Institute for Philology and Ethnology of the Neth. Indies) the Hague; - 14 v. Galenstraat.

5. Koninklijk Nederlandsch Aardrijkskundig Genootschap (Royal Netherlands Geographical Society) at Amsterdam; - Office, 28 Saxen-Weimarlaan.

6. Geologisch-Mijnbouwkundig Genootschap voor Nederland en zijn Koloniën (Geological and Mining Society for Netherland anditsColonies;-Inquiries should be addressed to the president, Mining Institute at Delft.

7. Het Batak Instituut (The Batak Institute) at Leiden. This society makes a special study of the Batak countries.

8. Het Atjeh-Instituut; het Bali-Instituut; het Oostkust van Sumatra-Instituut; het MinangkabauInstituut; het Zuid-Sumatra-Instituut; het MolukkenInstituut; (The Atjeh Institute; the Bali Institute; the East-Coast of Sumatra Institute; the Minangkabau Institute; the South-Sumatra Institute; the Moluccas Institute). - All six of these, which are run according to the example of 7 , were established at the instance of the Colonial Institute, and cooperate with it.

9. Regarding various districts and especially for ethnological and linguistic material, valuable information may be obtained from the Board of the Neder- 
landsch Zendelings-Genootschap (Dutch Missionary Society) at Oegstgeest (near Leiden).

$B$. INSTITUTIONS IN THE NETHERLANDS INDIES:

1. Koninklijke Natuurkundige Vereeniging (Royal Physical Society) at Weltevreden, to which at present a Committee for Vulcanology is attached.

2. Bataviaasch Genoootschap voor Kunsten en Wetenschappen (Batavian Society for Arts and Sciences at Weltevreden.

3. Indisch Comité voor Wetenschappelijk Onderzoek (Indian Committee for scientific research (cooperates with No. A 1).

C. Among the Government institutions in the Indies the following should be mentioned.

1. 'sLands Plantentuin (Government Botanical Gardens) at Buitenzorg (biology).

2. Meteorologisch Observatorium (Meteorologic Observatory) at Weltvreden.

3. Hoofdkantoor van den Mijnbouw (Head Office of the Mining Department) at Bandoeng (geology).

4. Laboratorium voor Zee-onderzoek (Laboratory for Oceanic Exploration) at Weltevreden.

Among the larger libraries, where scientific works on the Netherlands Indies are to be found, the most important is, that of the joint institutions $\mathrm{A} 3$ and $\mathrm{A} 4 \mathrm{at}$ the Hague, called Colonial Library (14 v. Galenstraat: 
open to the public $10-4)$. This excellent collection is not only almost complete with respect to the Netherlands Indies but also contains a great number of volumes on East Asia and Australia.

The library of the Colonial Department at the Hagu e (entrance Binnenhof; open to the public during the ordinary hours of service) is likewise well provided and well arranged.

The University libraries may be consulted advantageously for many requirements. The Technical University at Celft contains especially geological literature, and the Agricultural University at Wageningen biological and agronomical works.

Maps and charts of the Indies are to be found in the Geographic Institute at Utrecht (Plompetorengracht: open to the public 9-5), in the library of the Colonial Lepartment, in the Royal Library at the Hague in the library of the Indian Society, and in the division of Hydrography of the Navy Department. The maps are sold at Smulders and Co's, the Hague, and the charts at the above-mentioned division of Hydrography.

As a general survey regarding special subjects for those who have a satisfactory knowledge of the Dutch language, the newly finished edition of the Encyclopaedia of the Neth. East Indies is to be recommended, whereas for references to the literature or bibliography the Repertory of Colonial Literature (after 1595) inay be used. Both works may be found in all the principal libraries. With special reference to geology in its widest sense an almost complete list of papers provided with annual additions has appeared (prepared by Dr. R. D. M. Verbeek) in the Transactions of the Geological 
and Mining Society (Nr. A 6), file 1912 and following.

In the Indies the best scientific library is that of the Physical-Society (Nr. B 1), which is located in the same building as that of the Central Library Society. The first also occupies a part of the library buildings of the Agricultural Department at Buitenzorg. In the library of the Batavian Society (Nr. B 2) there is to be found a copy of all printed matter published in the Dutch Indies.

The Government Institutions ( $\mathrm{C} 1-5$ ) are also provided with professional libraries. Maps and charts are to be had in the Indies in the Topographic Office, branch Hospitaalweg (maps), and with the harbor masters at Tandjong-Priok, Soerabaja, Makassar, Padang, Sabang, Pangkalan Brandan, and Samboe (charts).

Besides the museums belonging in the Netherlands to the common Universities, the Technical University, and the Agricultural University, there is still to be mentioned those of Natura Artis Magistra at Amsterdam and of the Colonial Institute at Amsterdam. In the Indies the Batavian Society possesses an extensive ethnologic and archeologic collection, and also coins and medals and manuscripts. The Government Institutions C 2 and C 4 possess professional museums.

Travellers are recommended to complete their preliminary studies chiefly in Holland, the libraries and collections being as as rule better provided and arranged there than in the Indies; an exception is the Govern- 
ment Botanical Gardens. For more up-to-date information the Indies are of course best suited, for there officials as well as private persons usually show the greatest helpfulness towards serious travellers.

A permit is necessary, even for a temporary stay in the Indies. To acquire this the traveller should apply to the local authorities, soon after the arrival of the steamer, and have portraits with him. The local authorities also are able to furnish information as to whether or not travel in the districts to be visited may be subject to any special conditions.

Special recommendations to the authorities of the districts which are the objects of study are very desirable. If possible the traveller should try to get them not only from officials, but also from personal friends. The traveller should also keep in mind, that nobody is obliged to help him. Therefore much depends on the behavior of the traveller himself. As a rule the people in the Indies are quite ready to help, provided the person in question is in earnest and deserving. For instance he should never fail to call upon the local authorities as soon as possible in case of a shorter or longer stay in a place (it is unnecessary if only passing). Not only is this a mark of respect to the Government, but the official is often able to serve the visitor in some special way, on account of his greater knowledge of the country and the people.

In various districts the Government has constructed little buildings (pasangrahans), where passing travellers can spend the night and where the native overseer can usually provide a simple meal. The terms are differ- 
Pl. I

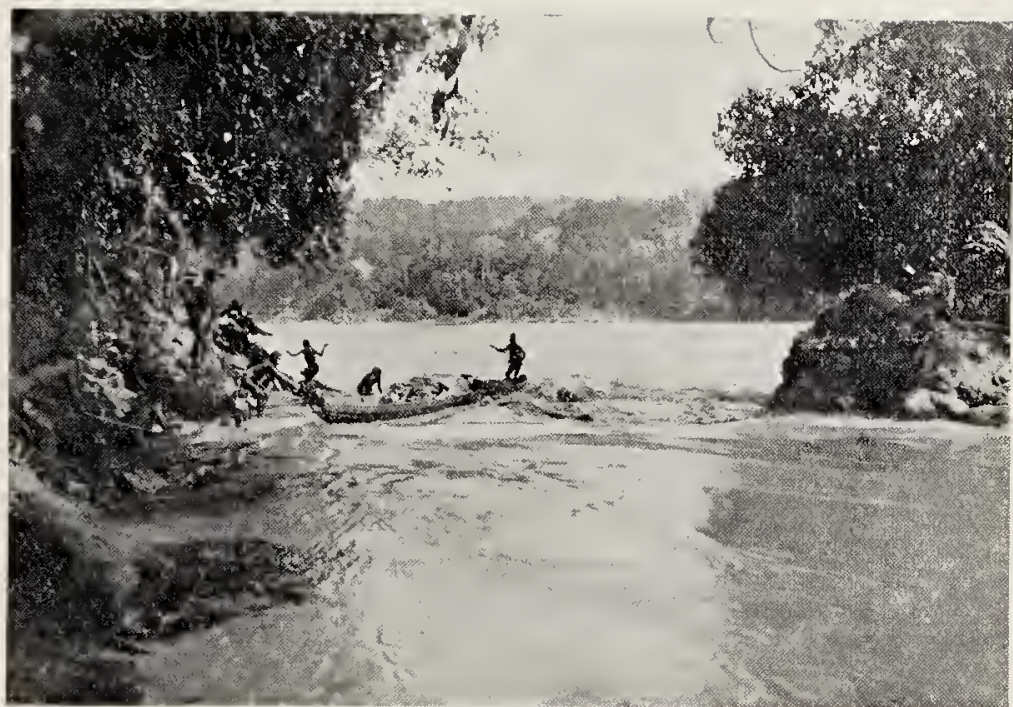

Transport in the rapids of the Mamberamo river in the Van Rees mountains northern New-Guinea

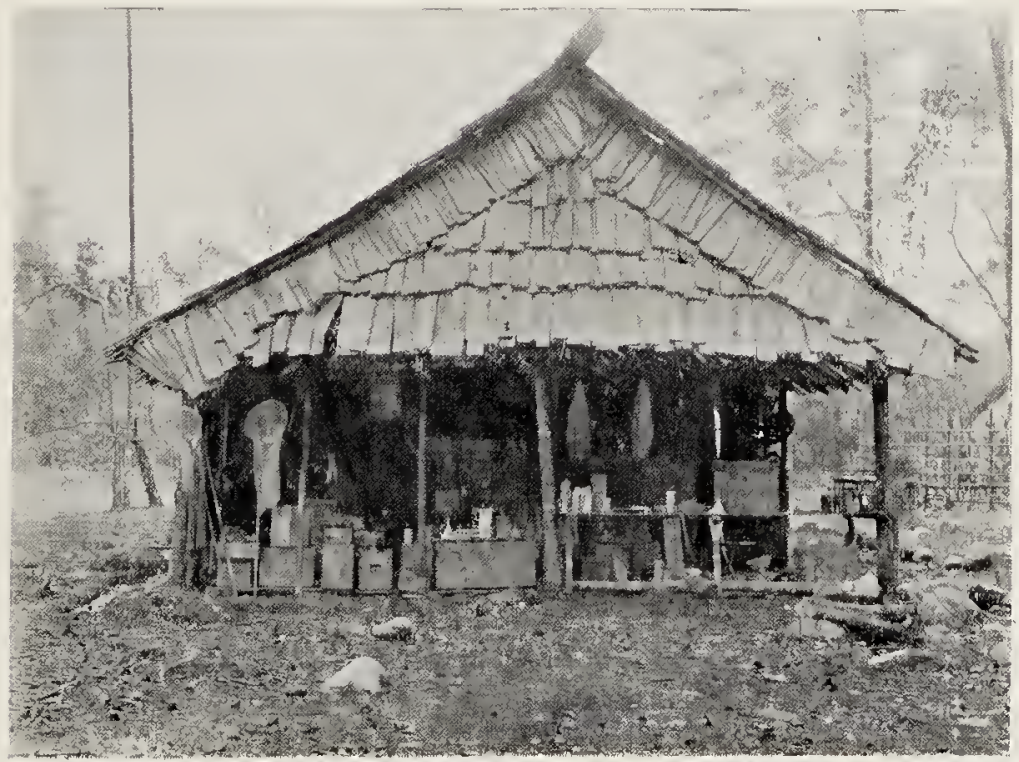

Laboratory of a scientific expedition in southern New-Guinea 

ent and posted on the walls. These pasangrahans are not intended for a longer stay but in some cases it is possible to get permission from the Resident under certain conditions.

For those who want to extend their activities to various islands, or to different remote parts of one of the larger islands, it will be necessary or desirable (except in Java) to travel occasionally by sea. The coast traffic in the archipelago is for the most part carried on by the large fleet of the Royal Packet Company (K. P. M.), which on application to its head office at Amsterdam (Prins Hendrikkade, Scheepvaarthuis) is prepared, provided there is sufficient supply, to send a time-table for the current half year.

Undoubtedly it is necessary for every traveller to have at least sufficient knowledge of Malay - the lingua franca of the Archipelago - to be able to hold a simple conversation. It should be observed here that both the English pronunciation of that language and the spelling differ a good deal from the Dutch. The natives' measures and weights which may vary more or less according to locality also should be known (see the Encyclopaedia and Annual Government-Directory of the Dutch East Indies).

Those who are not handicapped by time, as a rule, travel much more cheaply than those who are in a hurry. The latter therefore should possess a well-filled purse, in order to be able to hire the faster means of conveyance (motor cars, launches) for their private use, which are available now and then. (see sub Communication, p. 20). 


\section{GENERAL REMARKS}

In compiling this information travellers with a scientific object are kept uppermost in mind, though the greater part of it also will be found of use to those who travel with another object in view such as technical studies, etc. Besides, it should be observed that the information is primarily intended for the individual traveller rather than for some expedition consisting of several members.

a. For travellers with field professions (biologists and geologists) it is preferable to travel during a period of little or no rainfall, when the rain falls especially in the afternoon and leaves the mornings dry. Now there probably is no part of the world where the conditions of rainfall may differ so much within relatively short distances as in the Malay Archipelago. The traveller is therefore urgently advised to acquaint himself accurately with this subject. He may do so by studying the work of Dr. J. P. van der Stok: Wind and Weather, Tides and Currents in the East-Indian Archipelago (English edition), 1897, with many pictures and maps, or the article on "climate" (in Dutch) in the Encyclopaedia. - Volume II of the Handbuch der Klimatologie by Dr. J. Hann gives an exhaustive review of the subject. The Observatory at Weltevreden issues periodical reports on the rainfall in the archipelago; also a treatise on the general climatology of the Indies and environs by ${ }^{D}$ r. C. Braak is in preparation ${ }^{1}$ ).

1) Several parts of the first volume (with English summaries) have been published. Verhandelingen Koninkl. Magn. en Meteorol. Observatorium, Batavia. 
b. Before starting, the objects (clothes, etc.) that have to serve for journeys inland should be separated from those which are wanted in daily life. The latter should be separately packed in handy little boxes, preferably of metal, which can be effectually locked with an extra padlock of special make. The hinges of the cover should be placed on the inside, because otherwise theft is possible through striking out the pegs, since it is often necessary to leave them behind somewhere in rather unsatisfactory care. In order to be safe from damage caused by white ants, these boxes should be placed in empty kerosene tins, preferably on a spot that is not always in the dark. These tins can be had nearly everywhere.

c. Travelling men should live frugally and regularly, but they should not be economical with respect to their owen food, of course in moderation. Geological and geographical expeditions especially may often be very exhausting and without substantial food one's endurance is soon exhausted.

$d$. With the exertion required of the body, it should be kept in mind that the influence of a tropical climate in many respects is quite different from that of the temperate zones, particularly for those who have not become accustomed to the former by many years experience. It may be that many travellers shrug their shoulders and don't care for the warning, and when they become convinced of its truth it is often too late. If anywhere in the world the expression "slow and sure wins in the long run" holds good, it is surely applicable in the Indies.

e. Wounded feet, a common complaint in the jungle, 
should not be neglected but carefully attended to. If the wounds are somewhat bad or in an inconvenient place, complete rest for a few days is recommended. If one goes on in spite of the wounds, the consequence usually is that a forced rest has to be endured after all, and then of a much longer duration.

$f$. In their own interest travellers are urgently advised to let the female natives alone.

g. When travelling with geological or geographical purposes, a frequent change of guide is advisable. A native usually knows only the names of the mountains, rivers, etc., and the location of paths and trails in the general vicinity of his home. The answers of these guides should never be fully trusted and must be controlled as much as possible. A native does not like telling frankly that he does not know a thing. He always prefers inventing an answer or substituting a name of his own.

$h$. When investigations in creeks are necessary, the traveller should begin as far downstream as possible.

$i$. The authors have always been accustomed to walk behind the bearers (coolies), and to see to it that they kept near them. Natives when once left behind always avail themselves of the opportunity to rest every now and then, and having arrived at the goal for that day, the traveller as a rule has to wait a long time before the most necessary things arrive.

$k$. We often read of travellers who lost part or the whole of their collections or even their notes, in consequence of some mishap.

It also quite often happens that the notes have become almost unreadable here and there, or that they 
have been written so badly that one can make neither head nor tail of them afterwards. Besides travellers often disregard the possibility that the notes and collections have to be worked out by some one else. The authors have never had unfortunate experiences with their notes and collections during their many long travels and think their success due to the application of the rules outlined below. They take some time and give some trouble, but since the success of the expedition depends on what has been collected and noted down, sufficient trouble and time should be spared for it. In most cases losses are the consequence of carelessness or love of ease, a habit acquired by many strangers in tropical climates.

1. All notes made during the day should be worked over and copied plainly and in duplicate by means of carbon paper the very same day. The two copies should be kept apart and packed in different boxes. Never should a thing worth being noted down be put off till the next day, since new impressions generally make the details fade away rather soon.

2. Especially in the case of geologic work the samples should, if possible, be collected in duplicate; originals and duplicates should be packed separately.

3. The samples should be consecutively numbered; the practice sometimes followed of beginning with 1 every day, gives rise to mistakes. The number reritten boldly, together with a short indication of the place of origin, should be packed along with the sample in soft Chinese paper, which is obtainable in most Chinese shops. This parcel, with a repetition of the number, is wrapped in a newspaper or other similar packing ma- 
terial, on which the number is painted with Indian ink and brush. Everything should be written in ink! The duplicates should be distinguished in some simple manner or other, e.g. by asterisk. Lists of the samples are likewise kept in duplicate with indication of the number of the bag, and the number should be written down in the note-book at the exact place of origin.

4. When measurements have been carried out they should be delineated on a large scale the very same day, and the necessary mathematical reductions should be worked out immediately.

In this way inevitable errors, omissions, or indistinct notations are detected and may often be corrected at once or the next day. If drawings relating to the same district are completed, they should be reduced to the desired scale and compiled into a real map as soon as possible, at any rate before the district is left.

5. In case of transport by water, originals and duplicates of samples and notes should go into two different vessels, the two most reliable. If there are maps in simplo which must not be lost, they should be packed in a tightly closed zinc tube, which can be carried on a tape or string, and should be hung round one's own neck in somewhat dangerous spots. The tuwan (gentleman) is always the object of the greatest care.

6. Neither should originals and duplicates be carried by the same person during a period of land transport. The complaint is sometimes heard that the porters throw off parts of their loads. When this is not the consequence of too heavy loads, it can only be prevented by the authors' method of packing the 
samples in strong canvas bags which, when filled, weigh $1 / 2$ to $1 / 3$ of a man's load and which are closed with a string and a lead seal. On the outside the bags should bear a clearly visible number. A porter will only very exceptionally dare to throw away a whole bag, even less break a seal.

\section{OUTFIT}

The question of the private outfit is considered here. The scientific one is left to the explorer.

1. Clothes. The traveller may choose between suits (trousers and coat buttoned up to the throat) of white or khaki drill. The former are without doubt cooler to wear, but they soon get dingy. It is recommended to have the coats made with spacious pleated pockets. The junior author always wore flannel undershirts in the Indies and after a quarter of a century's jungle work never had a bit of rheumatism. If the traveller does not like wearing flannel, he should be especially careful not to catch a cold.

2. Shoes. The ordinary canvas shoes, though very convenient, are not recommended for long journeys on foot; walking in streams, which is so often inevitaable in geologic work, wears them out very soon. Most satisfactory seem to be easily fitting (but not wide) leather shoes. Hungarian leather is to be preferred, which should be kept supple through regular greasing with cod-liver oil or linseed oil and which by no means should be dried near a fire. Shoes made of hard and stiff leather should never be used. If stiff they should be moistened in water beforehand and put on 
damp. Boots with high legs are heavy and less practical. Low shoes with puttees are preferable though these are somewhat warm. The authors always used puttees with straps and front flaps, to which various advantages are attached, and by means of which the intrusion of insects (especially blood-suckers) is almost prevented, especially when the legs of the trousers are put inside the socks.

3. Headwear. A light bamboo hat, such as the military men wear, is very convenient. However, in a dense forest in a newly cut path and particularly when measuring by means of telescopic instruments a hat may cause great trouble. Therefore a cap should always be ready at hand.

4. Raincoats are very warm and can be used at most only in the mountains. The Mattamae raincoats advertised at present, which weigh only one pound, seem very satisfactory in open country.

5. Sleeping requisites. Though camps beds are sold in the shops, they are as a rule not strong enough to stand the rather rough treatment and many transports. The best thing is a so-called telescope camp bed, which should be carefully examined beforehand and reinforced in its weak spots. A thick mattress should be made to fit and packed along with the required pillows, blankets, sheets (and the mosquito curtain), the whole outfit rolled up in a bag of strong oiled canvas which can be closed with a rope and padlock (like the linen-bags used on board the steamers). As a protection against mosquitoes and other flying insects a mosquito curtain (klambu) should be made round the camp bed. Height about $2 \frac{1}{2} \mathrm{~m}$. : the 
Pl. II

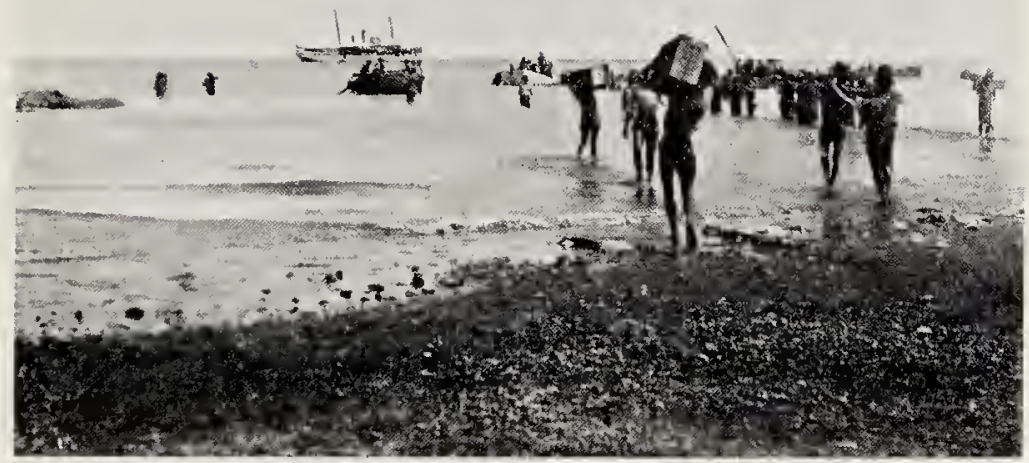

In the Moluecas. Transport of seientific collections to the steamer

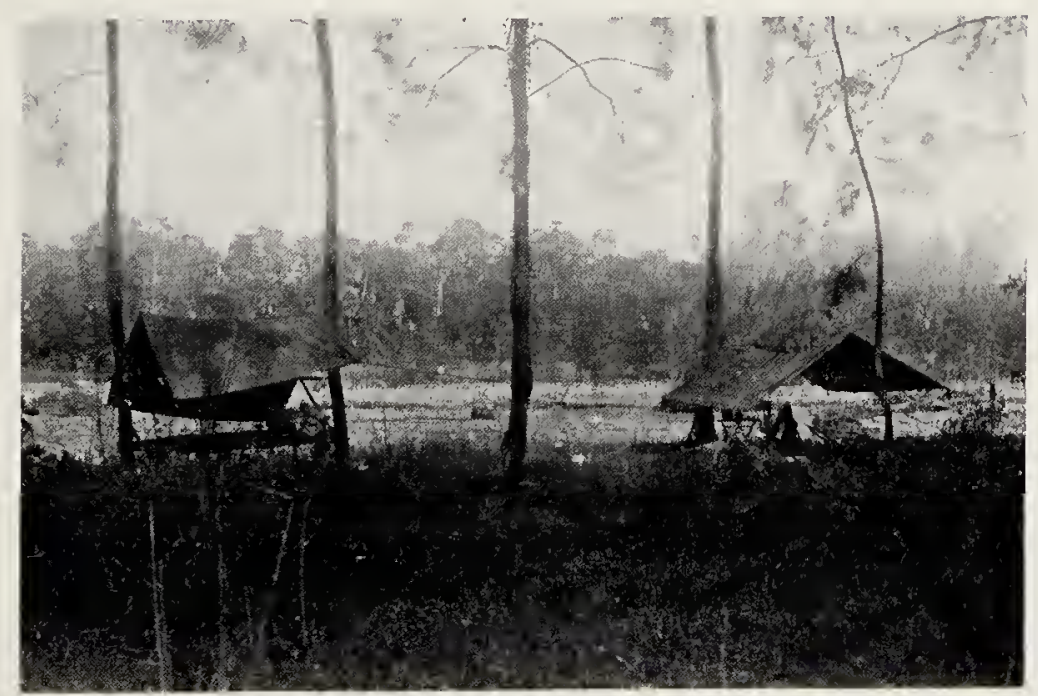

Simple camp for one night near a river on Timor 

top (tenda) material is made of strong cotton or thin linen; the sides of mosquito netting (such as is also sold in Europe) not too closely woven. The two halves of one of the long sides pass over each other at least 0.60 meter to serve as a passage. On the four corners

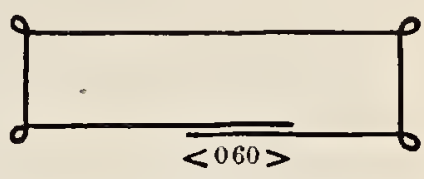

Fig. 1. of the tenda are fastened small but strong loops to draw up the mosquito net by means of a piece of tape or string.

6. Field table with detachable top, or a folding table, and folding chair to match are included in the outfit. The chair may or may not have a back to it. Both should be made of light but strong and above all dry wood, so that the table top may not warp in the tropics. If preferred the table can be made in the Indies, but the common wood, teak or djati, is rather heavy. There are good models at the mining department at Batavia. An easy chair may be of great comfort. The junior author lately had the pleasure of learning about an elegant inexpensive very light, but strong and comfortable chair of American make, which can be quickly taken to pieces and put in a small case; it was bought at the well-known stores of Simon Artz at Port Said. It was used continuously for months under unfavorable circumstances and is very much to be recommended.

7. For lighting, the American kerosene travelling lamp in a case should be taken, which, except the chimney, contains no fragile parts and may be packed and carried very easily, the oil remaining in the reservoir. Carefully packed extra chimneys should not be 
forgotten. All other material for lighting except kerosene oil is unsatisfactory, since it alone may be obtained easily at all places along the way.

8. Many travellers take a fultering apparatus for drinking water, the so called Berkefeld filters are common. While there is no objection to filtered water, the authors deem it more practical to drink only tea, either hot or cold. The cold tea is carried in a bottle with swing-wire stopple.

9. Eating utensils. Plates, dishes, mugs, etc. of enameled iron or aluminium are recommended, and iron fryirg-pans and cooking-pans should be included. The smallest number of fragile things and no more than absolutely necessary should be bought; new supplies are often obtainable in native shops.

10. Traveller's medicine chest with the most needful medicines and surgical appliances for the ambulant traveller and a more complete collection for those who intend to stay in a limited district for a longer time should be obtained from a druggist. They should be packed in the Indies; some chemists have them ready for use. Attending a class for first aid and for wounddressing is very commendable. Though medical aid is an excellent means of gaining the confidence of the population, the inexpert traveller should not be tempted to the treatment of more complicated cases. If need be he had better give an innocent remedy rather than refuse help. Castor oil and quinine sometimes work wonders! An often recommended article is serum against snake bite; our opinion is that this may as well be left at home. First, the traveller, when sufficiently careful,- stands very little chance of being mortally 
bitten (the authors have never been bitten in the snake countries of Borneo and Sumatra during their stay of many years) and secondly the remedy is seldom directly at hand when needed. Thorough pinching and sucking of the wound immediately after the bite, with tying-off is the best remedy. It is advisable to carry liquid ammonia as an excellent remedy against the bites of smaller insects and to keep it in a small bottle in a box-wood case in the measuring tin (see sub Surveying, p. 37).

11. Paper chest and cylindrical map cases preferably made of zinc and capable of being locked should be ordered for the trip.

12. Simple carpenter's tools of everyday use are necessary. The American cases, sold in the shops, in sets of a dozen or more tools are very handy. For bigger, coarser work the native usually prefers his own tools, with which he works better.

13. Camera. He who is not a skilled photographer is advised not to take an expensive apparatus, and even a good photographer will find by experience that it is not a simple matter to get good negatives in the Indies. Plates and films should be kept in double-bottomed boxes, provided with unslacked lime in small bags. A box or roll once opened should be finished as soon as possible. There is divergence of opinion about the question whether developing the plates should be done directly or at the end of the journey or expedition. The authors themselves think the first method the safer; partly because a failure can sometimes be retaken, and partly because developed plates can be protected against the influence of molds by varnish- 
ing them. Besides, plates of different sorts do not always behave in the same manner with regard to durability after exposure. If direct developing is preferred, this of course entails extra carriage, and for drying the plates absolute alcohol should always be used. The camera should be carefully kept, free from insects, but aluminium cases are not recommendable; they soon get rusty. The lenses should be regularly cleaned after use with a piece of chamois moistened with alcohol. Special attention should be paid to the fact that many cameras specially made for the tropics do not at all meet tropical demands.

14. For the traveller who is not too ambulant a small gramophone is to be recommended; the timidity of the natives is often conquered in that way. The instrument may also serve as recreation for the coolies and workmen. Records with Malays ongs are preferred by them and may be had in Holland.

\section{COMMUNICATION}

As has already been observed sub I (p. 9), the traffic between the different islands is as a rule only carried on by means of the boats of the Royal Packet Company, which keep up a fairly regular service even to remote corners of the Archipelago; to persons who can prove that they travel for scientific purposes only, the board of the Company at Weltevreden allow a reduction of $15 \%$ on passage and excess luggage. On application to the civil authorities the traveller may be permitted in some cases the use of the vessels which are at the disposal of the government officials. Besides, 
there are vessels under European or Chinese management on service here and there (Sumatra, Borneo).

Java occupies quite an important place in regard to land communication. A fairly extensive network of railroads and tramways covers a great portion of the islands, and the more important towns are all connected with the stations by means of highways passable for all vehicles and also as a rule to motor cars. Whereever these conveniences of travel are wanting, the country can generally be easily traversed along good foot or bridle paths. Almost the whole island has been cultivated. Only small parts, especially near the south coast are poorly accessible. Only there and on the slope of volcanoes the traveller may have recourse to the slow work of cutting his way through the jungle. Even in remoter districts there will generally be an opportunity of availing oneself temporarily of a native hut, so that bivouac building is seldom necessary. In short, in respect to traffic, Java approaches Europe much more than the rest of the Dutch East Indies. Many parts of Europe and America offer more difficulties to the traveller than Java. Because of the fact that the rivers are hardly navigable, river traffic is insignificant.

Sumatra. Here the development of traffic is advancing speedily. The present traveller and those of the nearest future will have a much lighter task than the pioneers of previous years. Compared with Java and the islands to be mentioned hereafter, Sumatra is in a kind of transition stage. Some parts have already been cultivated so intensively and have been provided with such a network of beautiful roads that they are nearly equal to Java in respect to conveniences (Deli, 
parts of Sumatra's west coast and of Palembang). On the other hand there are still vast regions devoid of any modern form of communication.

With respect to the eastern half of the island there are numerous rivers navigable far inland, so that the traveller may advantageously make use of water traffic.

Railroads and tramways are still rare; although some are in the course of construction. In recent years a regular motor car service has been established $\mathrm{bi}_{i}$ the Government between the principal places; chiefly in behalf of postal conveyance, the extension of this service having followed the improvement of the highways. There are motor vans, on which there are seats for 5 or 6 first-class passengers, room for a fairly large number of natives and a limited quantity of luggage. They do not cover more than about $150 \mathrm{~km}$. a day, and the seats are not very comfortable, but they are convenient and cheap. Such conveyances are to be found in Benkoelen, Palembang, Sumatra's west coast, Tapanoeli, and Deli. The traveller can obtain at Weltevreden at the Department of Government Works (Gouvernements Bedrijven), and of course on the spot, further information about time-table, etc.

In addition, private motor cars are to be had in many places, and sometimes even motor vans which are, however, rather expensive. The luggage therefore will usually have to be conveyed in native carts (pedatis). It should be borne in mind, that these do not carry very much and do not cover more than $20 \mathrm{~km}$. in 24 hours. Since the same cart does not go far from its station, the goods have to be transferred several 
times if the distance is considerable. In that case the traveller will do better to apply to a contractor and draw up a written contract.

In Sumatra the distances along the highroads are indicated in various ways. The old "Sumatra paal" (distance 1 nautical mile $=1851 \mathrm{~m}$.) has nearly everywhere been replaced by the "Java paal" (1507 m.), while the roads for motor traffic have been provided with kilometerstones.

From Palembang there is a regular service with socalled sternwheelers along the Moesi River and its principal tributaries (by the K. P. M. and by Chinamen). In these boats there is sitting and sleeping accommodation for European passengers. However, they cannot always reach their terminus in the dry monsoon. Some of these vessels also, as well as some steam launches, can be hired for private use.

When going between towns without train, tram, or motor car conveyance, the traveller has to take recourse either to small native carts, offering little comfort and less room and which consequently are very tiring on long distances; or to riding on horseback. Not everywhere, however, are horses to be had. The harnesses should be thoroughly examined beforehand and mended if necessary. At the same time it is good advice to have always a piece of strong string at hand since the native driver only mends things when they are badly broken, and mark how they do it!

Borneo is the country of water traffic. All the larger rivers (as far as the head stream is concerned) are navigable for steam launches and other vessels of light draught far inland, and great use is made of them 
from Pontianak, Bandjermasin, Samarinda, and other places. On most of the tributary streams, however, the traveller has soon to struggle with rapids and falls, which render other traffic than smaller rowing boats impossible. To conquer these obstacles special guides from the nearest surroundings should always be taken, as they only are acquainted with the various peculiarities of the rapids. Travellers are earnestly advised never to interfere by any personal commands during the passage of such spots. As contrasted with this, transportation by land is exceedingly burdensome. Real highways are wanting; what are sometimes called such, have no claim to that name, except in the immediate surroundings of the chief towns. Bridges are rare. Neither riding nor draught animals or vehicles are to be had. The traveller therefore has no other recourse but the footpaths, which are hardly ever kept in repair. For people who are in a hurry, Borneo is not a very satisfactory country.

For those who want to travel by water continuously for a long time, it is recommended to purchase a suitable good-sized rowing vessel (bidar) in one of the bigger places and to have it furnished according to their own taste for day and night use. A second boat of a smaller size (cooking proa) is likewise a desirable thing as an abode for the cook and a storage place for food. Other vessels may be locally hired for the time needed. Inquiries concerning prices, wages of rowers etc., should be made from the government officials or harbor masters.

Celebes. In sharp contrast to Borneo the rivers of Celebes are almost unnavigable. Transportation there- 
fore will have to take place exclusively by land. The relatively slight breadth of the arms of the island usually enables the traveller to use one of the seaside places as a center for various short trips and by doing so to keep in contact with the outside world. The high mountains that have to be crossed are often difficult to ascend and render an expedition to Celebes very tedious. However, an extensive network of roads is being constructed, improved, or repaired so that in a few years presumably quite another picture of the island can be drawn. Even the construction of railroads is now beginning. In some parts of Celebes horses may be used for riding and for carrying goods.

New Guinea is, of all islands of the Dutch Indies, undeniably among the least accessible. Moreover, it is much farther away from Java than the others, so that communication with the rest of the world, opportunity for new supplies, etc., is much more troublesome than in the other parts of the archipelago. Of late two stations for wireless telegraphy have been built on the north coast.

In this island the traveller meets with a difficulty, which is not at all or but little to be taken into account in other parts of the archipelago. This is the fact that the attitude of the natives is not always friendly. Unless confined to the coastal fringe, exploration is only possible for large expeditions with very ample resources, supported by military help from the Government.

Starting from the south coast even distant inland places can be reached comparatively easily by ascending the numerous rivers. On the north coast one river 
only, the Mamberamo, forms the chief way of entrance. This river, however, requires particularly strong launches because of its uncommonly strong current.

Remaining islands. Only a few of the remaining islands are so large that they may not be traversed in several days. As to roads, most of them are still in a rather primitive stage, though of late great improvements have been made.

Travellers who wish to visit several islands in the eastern part of the archipelago but can spend only a limited time in the study of each one, and consequently have to make repeated sea voyages, should take into account the monsoon wind and the currents, which are often very strong, because if they have nyo a sufficiently strong steamer at their disposal thet will have much difficulty and danger during the windy season. Landing is especially dangerous on most of the coast during times of strong winds.

Hence before undertaking such voyages very reliable information should be obtained as to the best season, (Navy office, Packet Company).

The southern islands are sparsely wooded and can therefore be more easily crossed than the northern ones, beside horse traffic is frequently available there (Soemba, Timor).

\section{INTERCOURSE WITH NATIVES}

a. With the carriers and the workmen. It is only in a few parts that the ordinary native can understand some Malay, but even in such favorable cases the traveller had better give his orders through a Malay- 
speaking mandor (overseer), because as a rule he has more experience and ability in making the men understand the meaning of the words and grasp what is wanted.

Treat the people well and above all be strictly just, especially in a pecuniary respect, and see to it personally that they really get what is their due, and keep an eye on the mandor. Never use corporal punishment, more is achieved with words with natives than is generally supposed. Bold or rebellious elements should be simply dismissed. In many respects natives are like children; treat them as such, that is do not be needlessly severe, and humor them occasionally if what they want to do is not exactly wrong even if you would prefer things done otherwise. Do not be peevish, and don't be a dog in the manger.

If a traveller has carriers or workmen in his service, who do not have their homes in that region, they should be made to understand beforehand that without exception no damage or robbery of property of the population will be allowed (especially theft of fruit or otber growth). These abuses will rarely occur with inhabitants of the region, since they know the current manners and morals. It should not be forgotten that the population holds the traveller responsible to a certain extent for the good conduct of his people. If misconduct happens to occur it is best to pay the damage as far as it is reasonable and deduct this amount from the pay of the culprit. If the latter is not satisfied, then refer the case to the local authorities.

Giving advance money to carriers and other workmen is a general evil in the Dutch Indies, for which 
there seems to be no help. This advancement has to serve for food for the family left behind, for the purchase of some travelling articles, for paying debts, etc. The people always try to get as much as they can, but as a rule deduction is possible by bargaining; the way of paying back should be directly agreed upon. We were accustomed to give only exceptionally a second advance during the same journey, and this only in small amounts. The junior author had sometimes recourse to the scheme of letting the people organize clubs, the members of which stood surety individually for the advances or debts of one of the members. The plan, does not always meet with success, but it may be tried since it gives the traveller a better guarantee against running away of the natives. However, with a little prudence and skill large sums of money need never be lost by default.

b. With the populace. If you want something of the natives, pay what they ask in cash; if you think it too much, try to bargain, but never take anything without sufficient payment. Not only do you antagonize them by doing so; but the autorities also, if it becomes known to them (which is highly probable), will be most offended at it. Inquire beforehand what the population has for sale and make your selections accordingly. Salt and tobacco for cigarettes are two articles much in demand, in return for which more is often to be had than for money. A quantity of them should therefore always be brought along.

In most cases it will be necessary to carry on conversations with the population by means of an interpreter. We must advise ethnologists not to try to pen- 
etrate into the spiritual life of the natives by asking questions. They are very particular and mysterious in this respect. What you get as an answer is as a rule untrue or gives rise to wrong notions. Even the attempts of the local authorities and missionaries, who are in constant touch with the population and who have a perfect knowledge of their language, often meet with little success.

c. With the chiefs. There is of course a great difference between the chiefs of Bataks, Dajaks, Papoeas and those in Java and Mid-Sumatra, who generally represent their real native aristocracy and have attained a fairly high degree of civilization. Hence these latter ought to be treated with due respect for their accomplishments and position.

A chief of the first category is often outwardly but little or not at all distinguishable from the rest of the population. This, however, should not deceive one: for frequently they have much influence, especially the older ones, since influence increases with age. The rule is: win their good will by polite treatment. If you expect to need some chiefs particularly for your work, try to find out what you can most please them with and, if it is in your power, satisfy their wishes. Never bully them in the presence of others: they will never forgive you that.

\section{CURRENCY}

Though officially the East-Indian coins pass everywhere, in some parts but little can be done with them among the population. To be sure the number and ex- 
tent of these parts diminishes gradually, but it is advisable to thoroughly inquire about the conditions in the country to be traversed. One thing should be particularly looked to, in parts where money is accepted, viz., to have a suffcient quantity of small money, for food and also for the payment of wages. The native hardly ever has change, and if he has he pretends to be stupid.

Where money is not a tender, the traveller should have recourse to barter. Articles for barter should not be procured before the district in question is nearly reached and then only after accurate information has been gathered from the authorities or the mission as to articles which are acceptable, for tastes greatly differ in this respect in different districts.

\section{SERVANTS}

Obtaining a good travelling servant, who at the same time is a cook (a djongos, as he is called in the Indies) is one of the most important and most difficult matters. A really good travelling servant, that is, one who has travelled before and does not object to life in the jungle, is as a rule anything but submissive. Besides, many travellers have the bad habit of leaving everything to their man, of letting him keep the keys of the boxes, etc. Don't set the cat to watch the cream! The consequence of this is that the majority of such servants do not know the true difference between mine and thine. Especially in the case of a beginner, however, it will be almost impracticable to prevent theft altogether, yet much may be done in this direc- 
tion by not handing over the keys and taking the trouble of getting things out of a box oneself and particularly by inspecting the things not locked up regularly. If this conduct is put into practice immediately at the beginning of a trip and the servant notices that you keep an eye on everything, it may be that he gives warning, but also that if he is satisfied for the rest he gives up his attempts. Although actual theft should not be tolerated, yet the traveller should not be too strict in regard to petty offenses.

Bringing servants from Batavia or one of the other large seaside towns of Java to a remote island, however tempting it may seem, is always risky, for if the servant does not know that part of the archipelago by his own experience he cannot be kept against his will later on, and his voyage back to Java must be paid. The surest way is to get a servant through a friendly family, but it should not be supposed that this is done quickly. If this plan succeeds, the terms should be agreed on in the presence of witnesses.

In selecting help always beware of servants of mail steamers and hotels, who often apply, although a useful boy may sometimes be obtained through a reliable hotel mandor. If a really good boy is found, keep him contented and satisfied.

\section{FOOD}

a. Of the carriers and the workmen. The chief food of most natives is rice; in the eastern part of the archipelago it is quite or partly replaced by Indian corn (djagoong) and sago. If possible let them procure their 
own food: this saves much trouble. But is is not always possible, so that then the traveller has to furnish it. Do not think that the native does not mind what kind of rice he eats; on the contrary, he is very particular, and though if he had to pay for it himself he might put up with a cheaper and inferior quality, what he gets from his employer should be first-rate, as good as that used in your own home. If therefore it is necessary to purchase and bring along a large quantity of rice for native food, it should not be done except with expert and reliable advice.

With his rice the native eats other food, e.g. fish, red pepper, salt, cocoanuts, vegetables. It is essential to their health to vary this food and not to be too economical with it, of course with suitable moderation and judgment. If the country is suitable for it, the easiest way is to give them a certain amount of money daily, for which they have to procure their own additional food. In this case, however, there is the objection that the money received for food is often spent otherwise or gambled away. If the traveller buys, food himself, he should take care not to be cheated.

If the rice has to be brought along and kept for a long time, don't pack it in air-tight closed tins, as it soon grows musty in them. On the other hand it must not get wet: especially in the case of water transport, this should also be taken care of. Regular and thorough shaking of the rice is absolutely necessary and - if possible - thorough drying. Djagoong is much easier to keep and to carry. Fish too should be kept quite dry.

For the daily portions of food, local experts should 


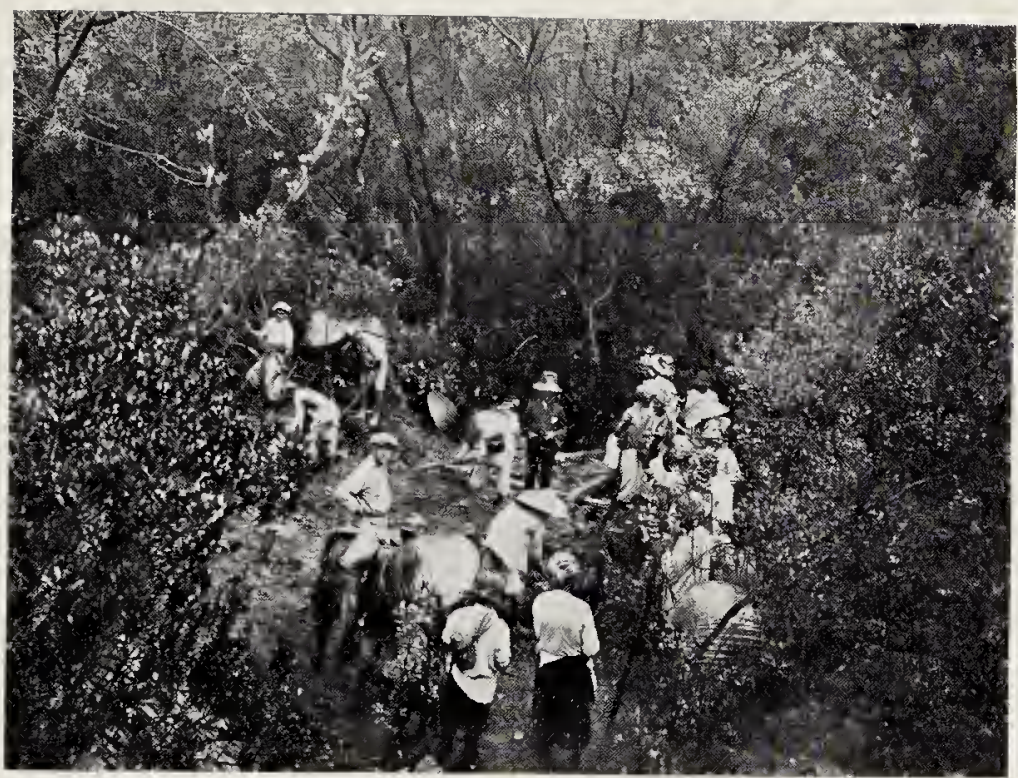

Preparation of camp site (slope of the volcano Papandajan, Java)

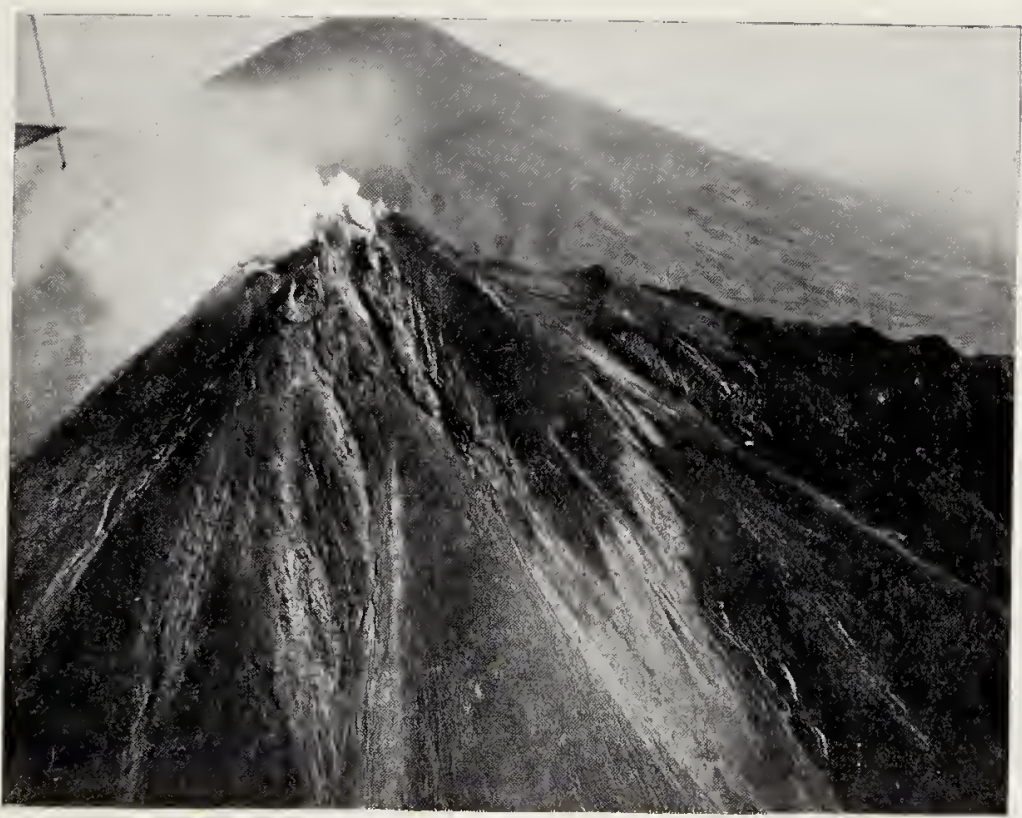

Aerial surveying (Volcano Merapi, Java) 

be consulted beforehand. Occasionally an extra treat should be given, preferably after uncommon work, so that it comes somewhat in the form of a reward. For this purpose a piece of venison, a goat, a couple of fowls, fresh fish, and the like and some tobacco will serve.

b. Of Europeans. Frugality in food is advisable to any traveller. He who can get accustomed to the tiffin (rice table) will soon experience that this is a great help to those who have to work inland. Rice may be procured nearly everywhere and most of the additional food can be brought along in bottles, dried or as "sambal" if one cannot get in on the spot, as for example the dried meat of deer or boar (dendeng). A native woman should be consulted as to both food and its preparation.

Whoever has time and ability will often be able to get fresh meat by hunting it, while near the rivers fresh fish is often to be had. For those who are able in this way to suit themselves to the country, there is indeed no troublesome food question and moreover the expenses are very low.

Whoever does not like this or cannot do it has to take recourse to tins, which are always heavy and expensive to carry and the renewal of which is difficult or impossible. Fruit is often rare and depends on the season. For those who want to eat fruit regularly, tins of Californian fruit are indispensable.

\section{PACKING}

On journeys inland no heavy or bulky objects should be carried along. If they are inevitable for

Hints I 
some reason or other, they should by all means be made in such a way that they can be taken to pieces. No individual article should weigh more than one man can carry; the transport of objects by two or more people on poles (peekolans) is only possible on good roads, and even then the traveller is by no means sure of finding people willing to carry loads in that way. In many parts the native carries the load in a rotan basket or in other cases by a sling round his forehead or across his shoulders and breast. Those loads for one man must not exceed $16 \mathrm{~kg}$. in mountainous regions and $20 \mathrm{~kg}$. on level ground. Chinese can carry more, and these are paid as agreed and according to weight.

If forced travelling is necessary, diminishing of loads, i. e. increase of carriers, or leaving behind goods is required.

At every departure the way of packing should be personally superintended, and good care should be taken that the loads are divided fairly and not changed on the road, especially if this is detrimental to the objects. Though wilful damage will seldom occur, few natives have a notion of what is meant by careful treatment. A simple Chinese balance (datjin, big model) or a Salter's spring balance are necessary to make the apportioning of the loads as accurate as possible and to convince complainers of fairness.

Kerosene oil is carried in the tins used in the Indies; the traveller should pay attention that it is not wasted in lighting fires. Undamageable objects should be put loose in the basket after noting the quantity and kind, and the carrier should be made responsible for the contents. Clothes and other articles not proof 
against the dampness should be packed in small boxes covered with thin leather and provided with a lock. These boxes are sold in various Chinese shops at the principal places. They are light, strong and watertight, but they should not remain too long on the bare ground.

\section{BIVOUAC-BUILDING}

a. For one night. If the night cannot be spent in a pasangrahan, or native hut, or if there are objections against this kind of habitation the Indian climate as a rule permits the use of a simple shelter made of a framework of forest wood, which the coolies (at least in woody districts) construct in a very short time. This, however, is advisable only in regions where there are no beasts of prey in the vicinity. Roof and walls are made of leaves or alang (a long and strong kind of grass). Of course the roof is usually not quite watertight and not proof against heavy showers or strong winds. If travelling in the rainy season is necessary, the traveller will be compelled to bring a water-tight roof covering or to use a good tent, which, however, in order not to be too heavy, should be small. Oiled or rot-proof canvas seems to be best. Some travellers seem to have had unpleasant experiences with silk tents. The junior author always preferred making use of the native dwellings if there was a possibility, first for convenience sake, and secondly to have a better opportunity of gathering necessary information, hiring guides, buying food, and keeping in contact with the population generally. 
b. For a longer duration. As a rule it will be possible to have a simple temporary building erected from forest wood. It is recommendable to draw a ground plan of it, to indicate the height of walls and ridge and then to contract for the whole for a certain sum within a definite time. One should make sure that the contractor really understands what is meant and the traveller should not fait to inspect the progress of the building now and then. The roof covering will have to depend on what the land furnishes. The most essential thing is that the hut is made water tight. If there are not too many objections to transportation, it may be possible to bring good roof covering from the seaside town (kadjang mats, which are in general use for the roofs of the bidars); otherwise atap or alang, or sometimes both together with broad leaves, may be made use of. All covering is protected against the wind by bamboo or solidly fastened laths. The walls are best made of beaten bark. Around the hut a deep ditch should be dug exactly below the farthest edges of the roof, having a drainage to the lower grounds.

Never neglect giving a feast (slamatan) to the workmen immediately after the building is ready. This is necessary in order to remain on friendly terms with the evil spirits!

Of course the bivouac should be built near running water, and the spot should be chosen personally. The camp for the workmen should be made downstream. If possible the traveller's house should be built on a tributary streamlet, and that of the workmen on the head river. See to it that the latter is situated on the lee side of the former. Round the whole bivouac a 
broad space should be cleared, first for the sake of health, secondly to get rid of the insects to some extent, and thirdly to furnish an opportunity for drying clothes, materials, and food.

\section{SURVEYING}

It is not only a great convenience but sometimes Fig. 2.

a necessity to have a small

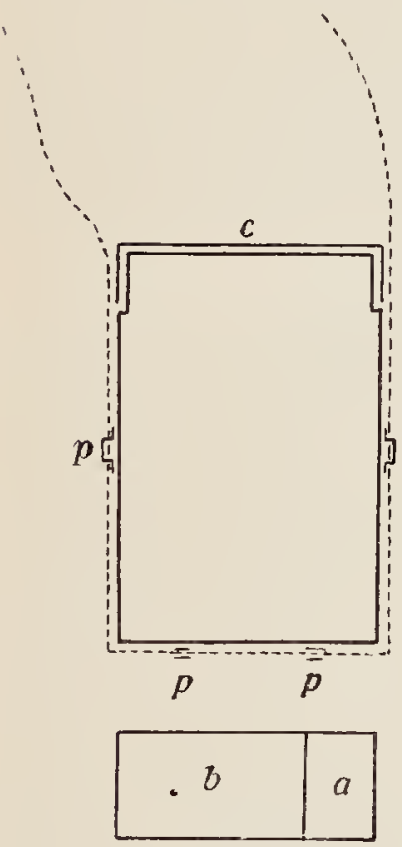

Cross-section. receptacle during the expedition for surveying book, sketch book, note book, etc. and further for pencils, scales, India rubber, and such trifles. For this purpose a little zinc box (tin soon gets rusty) should be ordered, as illustrated, with nicely fitting cover, $c$ (fig. 2). The space $b$, is so deep and wide that a couple of the necessary surveying books, sketch books, and a couple of note books easily go in; the space $a$ serves for the other things mentioned. Through the eyes $p$, which are soldered to the sides and the bottom, runs a piece of tape or string to carry it by.

As the existing maps will be found but rarely suited for detailed work, it will often be necessary for those who travel with geological or geographical purposes, and find no time for accurate surveys, to draw a rather 
reliable map, in the first place of the road followed, with its nearest surroundings and sometimes of sucl other portions of the land as, may be thought necessary. Therefore such travellers should practice, preferably before starting, the method of surveying by pacing, aided only by a common compass, and they should also be familiar with the estimating of heights.

If the course of a river has to be sketched, it should be done when travelling upstream, because in the opposite direction the speed is as a rule too great for accuracy. Such surveys are very inaccurate, even after long practice, and should if possible be used between points the situation of which is already known.

\section{COSTS}

These are very difficult to estimate; first because the means of communication are frequently modified, secondly because the personal element plays an important part in the work, and thirdly because the purpose for which one is travelling makes a great difference.

The time-table of the K. P. M. (Royal Packet Company) contain the rates of transportation. The wages of the helpers differ very much according to the reqiu to be traversed and also according to the season. To get a notion of it, 2/6 per man and per day should be reckoned, food included. For inhabitants of the district this amount suffices, but it will increase if the men have to be brought from elsewhere, as is the case for expeditions in New Guinea (for more information see the reports on sucl expeditions, as, for example, in the Joumal of the Royal Dutch Geographical Society). 


\section{NOTES ON TRAVEL IN SOUTH AND EAST AFRICA \\ BY \\ PERCY A. WAGNER \\ D. Eng. D. Sc. F.G.S.F.R.S. (Sa) \\ Geological Survey, Pretoria. \\ and \\ TUDOR G. TREVOR \\ A.R.S.M. \\ Inspector of Mines, Pretoria.}





\section{NOTES ON TRAVEL IN SOUTH AND EAST}

AFRICA

$\mathrm{BY}$

PERCY A. WAGNER and TUDOR G. TREVOR ${ }^{1}$ )

\section{INTRODUCTION}

The amazing progress of geographical discovery and the rapid extension of railways have completely altered the nature and scope of exploratory work in the portion of Africa under review.

At one time the object of every explorer was to penetrate the continent to as great a depth as possible or to cross it, making an accurate map of his route and incidentally gathering whatever information he could in regard to the native races, the economic products, and the geology, botany, and zoölogy of the regions traversed. In this way the veil that had so long enshrouded the Dark Continent was gradually lifted, and by the end of the nineties of the last century there remained very little of the surface of southern and eastern Africa that was completely unexplored. This era - the heroic age of African exploration — was followed by the era of the scientific traveller whose work, also mostly of the nature of hurried traverses

1) With the collaboration of A. W. Rogers, A. L. Hall, Mr. and Mrs. H. E. Wood. 
with some definite objective, was greatly facilitated by the existence of railways and roads constructed in the meantime and generally following closely the original routes of the early explorers. Today a network of railways and transport routes, still imperfect but rapidly extending, covers the sub-continent, and along them the settlement of Europeans has taken place at intervals and is proceeding steadily, so that the white communities are now firmly established in districts to which, until a few years ago, no explorer had succeeded in penetrating.

It is in the nature of things that the scientific exploration of the more remote districts thus opened up should have lagged far behind their settlement. Of many of the huge tracts of country lying between the newer and even some of the older railways we are, indeed, as ignorant, as regards recorded scientific information, as we were at the end of the era of the great explorers thirty years ago.

Exploration in the future will be directed to the intimate study of such areas, and, except in very special circumstances, it will seldom be necessary for the explorer to journey more than 300 to 400 miles from his base on the railway.

Transport none the less continues to be the most important factor and will, therefore, be dealt with first in the following notes, in which the writers have endeavored, as far as possible, to avoid ground already fully covered in standard handbooks of travel.

\section{TRANSPORT}

Apart from railways, with which we are not here 
concerned, there are seven methods of transportation now in vogue in the part of Africa under review. They are enumerated in the table of contents and will be separately treated. Each has its own appropriate sphere, and to reach his destination from the railhead, even when travelling only a comparatively short distance, the explorer will often need to have recourse to several of them.

\section{a. WAGONS AND HEAVY CARTS DRAWN BY OXEN, DONKEYS, OR MULES}

The Ox wagon. The well-known heavy colonial wagon, drawn by from six to twelve yoke of oxen, which has probably been the most important single factor in the opening up of southern Africa, is still the favorite means of transit in those parts of the sub-continent free from the dreaded tsetse fly, though the spread of East Coast fever and other cattle diseases and the enforcement of quarantine regulations have in recent years greatly reduced its field of utility. Thus, in the Union and Southern Rhodesia the main transport roads are liable to be closed at any moment by an outbreak of fever somewhere or other in the country. Even so, the ox wagon finds very extensive employment in the territories named and in Bechuanaland, Southwest Africa, Angola, Portuguese East Africa, and the plateau regions of East Africa, as there can be no question that, particularly when supplemented by a motor car or saddle horses - or preferably both - it is infinitely the most convenient and reliable means of transport; the great advantage of oxen over other 
draft animals being that they feed themselves, are strong and tractable, and can if necessary go three or four days without water.

Wagons are of three types, namely: tented, halftented, and buck (i. e. bare).

A tented or full-tented wagon is 18 feet long and for some 16 feet of that distance is surmounted by a convex wooden frame and canvas roof. The internal cross measurement of the tent is from 5 feet 6 inches to 7 feet, and it is from 5 feet to 6 feet above the boards. A wagon of this description makes a magnificent caravan and can be fitted with boxes, folding beds, chests of drawers and any convenience that may be desired. As a travelling vehicle in which to reside and carry one's personal belongings nothing better could be desired, but it is unsuited for carrying other loads as it is very awkward to pack and unpack.

A half-tented wagon has a hood about 6 feet 6 inches long over the hind wheels, closed fore and aft by movable sails. The tent usually carries the traveller's bed -.. a spring mattress or so-called "katel" placed crosswise - and his personal equipment. The tent is perfectly weatherproof and, as nothing in it need be moved, mone can if desired sleep in it while the wagon is trekking. For a single traveller the half-tented wagon is an admirable vehicle, as the load goes on the untented portion and is easily accessible, while his own bed and belongings remain undisturbed in the tent. In hot malarious countries the latter should be lined, with green baize and its ends provided with movable mosquito curtains. For long journeys through thorn scrub and bush, where an ordinary wagon tent is liable to be 
torn to pieces, it may be advisable to replace canvas by thin sheets of galvanized iron, painted white so as to prevent excessive absorption of heat. A "tent" of this nature, lined with green baize, is, if anything, cooler than canvas and outlasts the wagon.

A "buck" wagon is a plain untented colonial wagon unsuited to any purpose except the conveyance of goods.

All three types of wagon are made in various sizes, the heaviest being used for oxen, the medium for donkeys, and the lightest for mules. A strong 18-foot wagon will carry anything up to 12000 lbs., but in ordinary, circumstances the maximum load is about 6000 lbs. For carrying heavy loads through sandy country wagons are sometimes fitted with broad-flanged iron or stcel wheels, but this will probably never be necessary with cxplorers' wagons.

The cost of wagons has increased enormously of recent years. Thus, whereas before the great war, a "buck" wagon could be bought for $f 70$ and a halftented wagon for $£ 85$ the present ${ }^{1}$ ) prices at Pretoria are as follows:

$18 \mathrm{ft}$. "buck" wagon . . . . $100 .-£ 115$.

half-tented wagon . . . £ 130. - £ 150.

full-tented wagon . . . £ 150. - £ 175.

Good second-hand wagons can be purchased for much less in all the large towns and villages. If a second-hand wagon is bought it should in the first place

1) May, 1922. 
be thoroughly washed and fumigated, as the tents are frequently infested with bugs and other vermin. It is also generally necessary to have the tires shortened before starting on a long journey.

Specially designed commodious travelling wagons provided with springs can sometimes be hired, but as a rule one has to have them specially built, in which case they cost at least fifty per cent more than the ordinary wagons. Wagons of this nature are supplied to the geologists attached to the Geological Survey of the Union of South Africa. They are generally broader than ordinary wagons, which is a great disadvantage in travelling through bush country.

There are also small spring wagonettes, suitable for ox, mule, or horse transport, but they are not of much use for long journeys as their capacity is low and they are very liable to capsize. Such a wagonette is shown in the background of fig. 5 .

Essential trekgearand equipment for a $\mathrm{n}$ ox wagon.

This comprises:

A complete trek chain with a number of spare yoke lengths and at least two dozen link and "D" shackles.

Yokes and spare yolies of South African manufacture.

"Yokeskeys" (the South African substitute for yokebows) and a large supply of spare yokeskeys.

"Riems" and "strops" (rawhide thongs). At least twice the number required should be carried.

Spare wagon pole. 
Complete whip, spare whipstock and lash.

Supply of anti-friction grease.

Strong screw jack.

Spare king-bolt.

Large waterproof wagon sail or tarpaulin.

Crowbar, crosscut saw, side axe, augers (1 in., $\frac{1}{2}$ in., and $\frac{1}{4}$ in.), spare bolts and nuts, 10 yards of stout iron wire, sailmaker's needle, thread, and palm.

The complete cost of the articles enumerated, including tarpaulin, should not exceed $£ 40$ at the outside. Where the wagon is hired most of the trek gear is generally included.

The wagon is generally provided with a stout, hinged wooden box known as the "voorkis," which serves as a driver's seat and is a convenient place for keeping tools, riems, lash, etc. It should be provided with a good padlock and kept locked, the key being entrusted to the driver or the conductor of the expedition if there is one.

Each wagon should also have its own water tank or barrel and three-legged kafir cooking pot. The size of the water tank or barrel carried will depend upon the nature of the country to be traversed. For work in very dry areas a 200 gallon steel tank is sometimes fixed on the fore part of the wagon. The alternative to a large tank is a separate two-wheeled water cart drawn by four or six oxen. This, however, adds greatly to the cost of equipment and the wages bill.

Wagon personnel. Two boys ${ }^{1}$ ) are required to look

1) Native males irrespective of their age are throughout Africa spoken of as "boys". 
after the oxen; one of these, the driver, carries the whip; the other, generally known as the "voorlooper," leads the front span of oxen by means of a strip of rawhide attached to their horns. The voorlooper is also responsible for herding and watering the animals when they are outspanned.

The driver is paid from $£ 2$ to $\& 3$ permonth plus food, and the voorlooper from $15 /$ to $20 /$ per month.

The usual daily rations for driver and voorlooper and other native servants are as follows:

2 lbs. mealie meal

$\frac{1}{2} \mathrm{lb}$. meat

2 ozs. sugar

$\frac{1}{2}$ Oz. salt

$\frac{1}{4} \mathrm{lb}$. tea or coffee per week.

Where meat is plentiful and meal scarce the meal ration may be partially replaced by meat, for which all South African natives have an inordinate craving.

It is the duty of the wagon boys to look after the camp and to do the cooking; also to make themselves generally useful in so far as this does not interfere with their care of the animals. They are always willing to do so, but as a rule are very rough-and-ready in their methods. A good personal boy with a knowledge of cooking and valeting is therefore invaluable and in any case such an adjunct to one's comfort as to be a necessity for essential work. Such boys are not easily had ready-made but with a little patience are easily trained.

Where several wagons and a large number of oxen are employed a competent white conductor becomes an absolute essential, and care should be taken that 


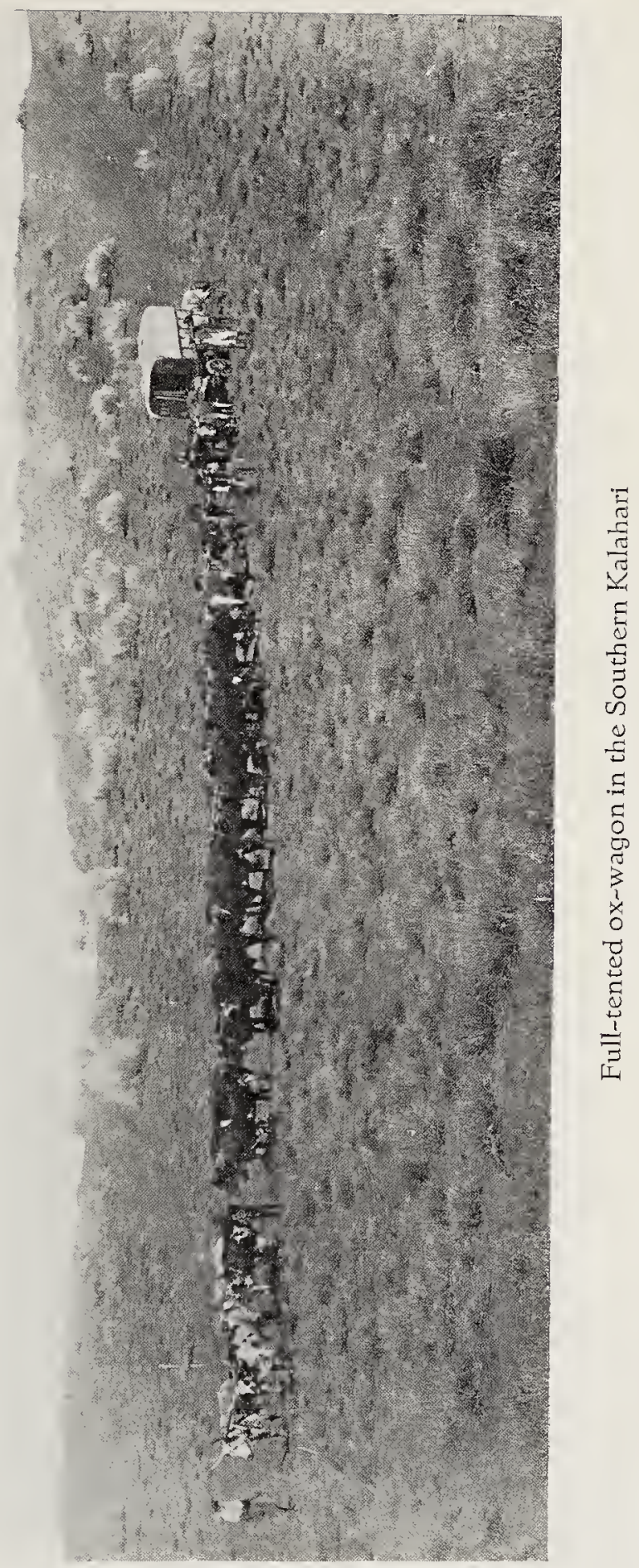



this conductor is selected either from the inhabitants of the district to be traversed or is at least a man accustomed to the conditions there prevailing. The ordinary Dutch wagon conductor is an uneducated man, rough in appearance and extraordinarily ignorant of everything not essential to his work but, on the other hand, extremely "veld wise" and wonderfully good at overcoming difficulties, having a natural gift for getting on without what are usually considered essentials and at making expedients. He is also an excellent pothunter and will procure game where no other European can find it.

Oxen. The number of oxen required will depend upon the weight of the wagon and the nature of the country to be traversed. As a rule sixteen suffice, but for sandy country such as the Kalahari, where in addition to the heavy going the animals have to do without water for long periods, twenty or even twenty-four oxen are required.

For long treks it is always advisable to take a few spare oxen. To negotiate exceptionally heavy stretches, such as the belts of steep sand dunes met with in the Namib and the Kalahari, or swampy ground, it is sometimes necessary to inspan as many as forty oxen. When travelling with two wagons this is easily arranged by detaching the trek-chain from the pole of one of the wagons and fixing it on to the end of the trek chain of the other. When one wagon has successfully negotiated the obstacle the double team is sent back for the other.

The best way of getting a wagon, or for that matter any form of wheeled vehicle, through a deep miry 
swamp is to "corduroy" the line of intended passage with logs, branches, or reed faggots which are picked up and used over and over again as the wagon advances.

Good trek oxen over most of the Union and Southern Rhodesia are now worth from $£ 9$ to $f 12$ In Southwest Africa and Bechuanaland the price ranges from $\& 7$ to $£ 10$. The selection of the oxen is a matter of considerable difficulty, and it is as well to leave the purchase of the entire team to some reputable firm or, better still, to the Boer conductor of the expedition.

The great advantage of trekking with oxen is that, in ordinary circumstances, they can be disposed of at the end of a trip for practically what was given for them. The same applies to the wagon and trek gear.

Rate of travel by ox wagon. A good team of oxen will draw a fully laden wagon over almost any kind of track at an average speed of $2 \frac{1}{2}$ miles an hour.

The duration of the single trek is from 3 to 4 hours, and two treks are generally made per diem when trekking by day only; the average rate of progression being about 15 miles. When travelling day and night, as is often necessary in dry waterless country, where most of the trekking should be done at night, much more rapid progress is made. Thus, one of the writers in July, 1910, traversed the dreaded 80-mile thirst between Gasamas and Nuragas in the sand veld of the Northeastern Kalahari (Grootfontein District, Southwest Africa) with two wagons in three days and two nights, without any of the oxen being the worse for the trip. 
The actual trekking time was 32 hours, which works out at exactly $2 \frac{1}{2}$ miles per hour. The day treks averaged 3 hours, and the night treks 4 hours.

When starting on a long trip through waterless country it is important to remember that oxen drink at midday. The trek should accordingly be begun in the afternoon after giving the animals a couple of hours to ruminate. By starting early in the morning, as is often done, 18 hours are added to the period that the oxen have to do without water. When, after traversing a thirst, water is eventually approached care should be taken to outspan the oxen long before it is reached, as the poor half-maddened animals have been known to dash a wagon to pieces on scenting water after being without it for three or four days.

Donkeys. Donkeys are if anything even hardier than oxen but are slower and not so satisfactory in sandy country. A good team of twenty will easily pull a load of $5000 \mathrm{lbs}$. at an average speed of from $1 \frac{1}{2}$ to 2 miles an hour. Apart from the fact that they are harnessed to the trek chain instead of being yoked to it the trek gear and general equipment of donkey transport is identical with that for ox transport.

Donkeys are immune to horse sickness and also largely immune to the bite of the tsetse fly, the Abyssinian breed being particularly resistant in this respect. They were very extensively employed in the campaign in East Africa, and though most of them eventually died they long outlived all other transport animals. They are extremely hardy and can, if well treated, subsist on almost any vegetation and go without water 
for two or three days, but they take longer to feed than oxen, and the slow pace at which they travel is heartbreaking to Europeans new to this form of transport.

Lions have a predilection for donkey flesh and attack and carry off donkeys in preference to almost any other animal. When trekking through lion country special precautions have, therefore, to be taken. The donkeys should never be allowed to stray far from the camp, and it is advisable at night to tether them to a stout rope stretched between two trees and keep an acetylene or oil lamp burning near them. A burning acetylene lamp suspended from a branch some distance above the ground has proved to be a very effective means of keeping off lions, having apparently an eerie effect on the king of beasts.

The price of donkeys ranges from $£ 5$ to $£ 7$ a head and harness for 20 donkeys costs new about £20.

Mules. Mule transport travels at from 4 to 6 miles an hour and is practicable for ordinary mules anywhere south of the latitude of Pretoria. North of this it is customary to immunize mules against horse sickness by innoculation, the immunity given being practically perfect.

Compared with oxen and donkeys mules are at a great disadvantage in that they require feeding over and above the natural grazing obtainable in most parts of the country. This renders them quite unsuitable for any work away from districts where forage is readily procurable. They also require more regular 
watering than oxen and donkeys and are not satisfactory in sandy country.

The price of immunized mules in the northern part of the Union and Southern Rhodesia is about $£ 30$ per head.

$O x$ carts. Second in dependability only to the ox wagon is the heavy ox cart, drawn by from 4 to 6 yoke of oxen. It corresponds with the back part of a halftented wagon and has the great advantage over the wagon that it can turn in its own length and is not so heavy on the animals, particularly in deep sand.

Ox carts are thus well adapted for travelling in rough trackless country, where sand dunes have to be negotiated. They can be strongly recommended for the exploration of those parts of the Namib where water is obtainable at reasonable intervals.

\section{b. LIGHT VEHICLES DRAWN BY ANIMALS}

For short journeys light two- or four-wheeled vehicles drawn by horses, mules, or even oxen were formerly largely employed, but the increasing popularity of motor cars is yearly limiting their use.

The spider, or buckboard. Except in sandy country the spider, or buckboard, is best suited for light horse or mule transport. It is a four-wheeled American vehicle, weighing altogether about $300 \mathrm{lbs}$, capable of seating two passengers and of carrying a great quantity of luggage. By blocking the springs upwards of $1 \mathrm{COO} \mathrm{lbs}$. can be carried. It can get over any kind of ground and 
is almost impossible to capsize, except by locking the wheels or turning too sharply. A good type of buckboard is shown in the right-hand corner of the plate.

The price of a buckboard is about $f 75$.

The Cape cart. This is the common two-wheeled vehicle of South Africa and is a sort of heavy dogcart. It is very clumsy, heavy on the draft animals, inconvenient for luggage, and apt to capsize, being inferior in every respect to the spider, except in cases where long stretches of heavy sand and steep dunes have to be traversed. Here a light form of Cape cart with broad-flanged wheels has proved very satisfactory. Carts of this type, drawn by from 6 to 10 mules, are very largely used on the diamond fields in the coastal desert of Southwest Africa, where waterless stretches of up to 40 miles with great belts of sand dunes have to be crossed.

The present price of Cape carts ranges from $£ 70$ to f 115 .

\section{c. RIDING AND PACK ANIMALS}

Horses and mules. South of the latitude of Pretoria, $25^{\circ} 45^{\prime}$, horses can be used with sufficient security for all general purposes, except in the coastal strip running through Zululand, Swaziland, and Portuguese territory, though it is not customary to use them for heavy transport. North of this latitude and in the coastal belt the risks of death from horse sickness are so great that they cannot be relied upon, though a 
"salted" 1) horse can be taken almost anywhere with reasonable security.

Immunized mules have in many districts proved very useful for saddle purposes, being extensively employed in Southern Rhodesia. Good riding mules are, however, proverbially difficult to obtain and at best are not nearly so tractable as horses.

The price of horses in the Union and Rhodesia varies from about $f 20$ for ordinary saddle horses to $f 65$ for a salted horse; and that of mules from £ 20 to $£ 45$.

Riding donkeys are used to some extent in East Africa and are quite satisfactory though, of course, slower than horses.

In purchasing saddles for South African work the pattern sold as "Colonial" with the largest possible " $\mathrm{D}$ "'s and web girths should be selected. The Colonial pattern saddlebags, folded over the crupper of the saddle, are much the best as they take no time to fix and are very capacious. Saddles, reins, and all forms of harness should be frequently dressed with "Dubbin" or saddle soap as they are otherwise liable rapidly to deteriorate.

Wallets are a nuisance and are not necessary unless it is required to take the greatest amount possible on a saddle.

African horses are accustomed to a heavy curb bit and single rein. Crupper straps, etc., and all fancy equipment should be avoided. Though a crupper or

1) A salted horse is one that has been attacked by horse sickness and recovered. 
martingale is necessary in mountainous country it can always be improvised out of a spare girth.

It is possible to get horses shod by the inhabitants anywhere in the Union, but outside the mountainous districts it is better to buy a horse that is not accustomed to being shod and to do without shoes as long as possible.

Pack horses and mules. In mountainous regions free from horse sickness and the tsetse fly, e.g. Basutoland, pack horses and mules remain the favorite means of transport. Horses are preferable to mules as they are less difficult to handle and have greater powers of endurance, this applying particularly to the Basuto pony, which is undoubtedly among the hardiest and most sure-footed of all breeds of horse.

For carrying packs, which should not exceed 200 lbs. in weight, the cross tree type of saddle is the best.

Pack donkeys. As pack animals donkeys are excellent, carrying loads of from 70 lbs.; their hardy and thrifty nature rendering them very suitable for this purpose in areas where the use of horses and mules is impracticable.

Riding and pack oxen. Riding and pack oxen were at one time largely used in the Kalahari and Southwest Africa and were as efficient for these purposes as they are for drawing heavy vehicles. They are, however, rarely seen nowadays as their training is a rather long and tedious process. 
Camels. For traversing the desert wastes of the $\mathrm{Na}$ mib and waterless bush or scrub country without road or tracks, such as is met with in the Kalahari and in Northeastern Rhodesia, the camel has proved invaluable and will doubtless continue to be employed: this applying particularly to the more inaccessible portions of the Namib, the exploration of which will have to be carried out with camels.

It cannot be too strongly emphasized, however, that the camel is a difficult and unpleasant animal to work with, and where there is a possibility of oxen being used they are infinitely to be preferred.

For South African conditions camels from the Canary Islands have been found to be the most suitable.

A good camel will easily carry from 300 pounds to 350 pounds at an average speed of about $2 \frac{1}{2}$ miles per hour and will keep this up for from 10 to 12 hours per diem.

Loads have to be carefully balanced, and it is well therefore, on starting on an expedition, to have all provisions and equipment put up in boxes or bales of from 150 lbs. to 160 lbs.

The packing of a camel requires considerable skill and, where these are available, should at the outset at any rate be left to practised attendants. The animals are made to kneel, and the balanced load is caught in a double sling of rope with two loops on either side.

For carrying water there are special camel tanks, but in Southwest Africa it is customary to fix two 15 gallon steel drums on to a simple saddle carrier as is shown in Pl. III, fig. 2.

Camels can go for ten days or even longer without 
water, but if possible should have water once a week.

As regards food it has been found on long treks in the Namib that 2 lbs. of oats per diem are quite sufficient to keep the animals in conditions, a they graze on brak bushes (Salsola and Aerva sp.), which are almost everywhere met with. Where, however, no vegetation of any description is present they should be given from $8 \mathrm{lbs}$. to $10 \mathrm{lbs}$. of compressed forage or lucerne per diem in addition to the oats.

In those parts of the Kalahari where the Tsamma melon grows, camels need neither to be fed nor watered.

Particularly in the Namib camels have a tendency to develop nasty skin sores and it is advisable to carry a strong antiseptic dressing for these.

\section{d. NATIVE BEARERS}

In those parts of the sub-continent over which the tsetse fly is distributed and in forest and swamp country the recognized and propably surest means of transport is by native bearer; this method being very largely employed in East and Southeast Africa and Angola.

Loads average 60 lbs. for one man and about 90 lbs. for two men (double load), so that all equipment has to be put in boxes and bales not exceeding these amounts.

The average rate of travel is about 14 miles per diem, but at the start a bearer should not be required to do more than about 10 miles.

Light steel boxes with locks or fibre cases are best 
for carrying supplies, as they are impervious to the attack of white ants.

With regard to the packing and sorting out of the loads according to weight, natives should always be allowed to pack their own loads as they please, being adepts in this.

The caravan generally consists of a headman, who is in charge of the porters and caravan generally; one or two tent boys; a gun boy; a cook boy and cook's mate, who also do the washing; a post boy for carrying letters and dispatches; and the requisite number of professional porters.

Porters can be hired almost anywhere within the regions where this mode of transport is in vogue. It often pays to get them through the Native Commissioner of the particular district, as this ensures that they will not desert.

The number of porters required will depend upon the weight of equipment and food to be carried, the distance that is to be travelled, and the nature of the country to be traversed.

A porter's ration is $2 \mathrm{lbs}$. of mealie meal per diem, and in areas where no food can be purchased enough meal has to be carried to enable the expedition to reach its objective. To take a simple illustration, assuming the distance to be covered to be 200 miles, then at least 15 days rations would have to be carried, or in other words $30 \mathrm{lbs}$. per man; so that if the food and equipment of the party weighs $900 \mathrm{lbs}$. a minimum of 30 bearers would be required to carry it, with 3 or 4 additional bearers to carry food for the head boy, gun boy, etc. By making each bearer carry a $12 \mathrm{lb}$. bag of 
meal, sufficient to last him for six days, in addition to his $60 \mathrm{lb}$. load, the number could be reduced by 4 , but it is not advisable to overload bearers at the beginning of a long march.

Where meat can be purchased or game is abundant, the meal ration can of course be partly replaced by meat. It should be remembered in this connection that Mohammedans will not eat meat unless one of their religion has cut the throat of the animal before it is dead.

Wages. In Rhodesia native bearers are paid from $15 /$ to 25/ per month with their food. In East Africa, where the rupee is standard currency, the usual monthly wages for head boys, porters, etc. are as follows:

Head Boys . . . . . . . 25 to 40 Rs.

Porters . . . . . . . 10 Rs.

Gun Bearers . . . . . . . 25 to 30 Rs.

Tent Boys . . . . . . . . 20 Rs.

Cook Boys. . . . . . . . . 25 to 30 Rs.

A couple of Askaris are sometimes taken to guard the camp. They are paid $20 \mathrm{Rs}$. per month.

As regards equipment each porter receives before starting a new blanket and jersey, a cotton bag for his meal ration, and a cord to tie up his load.

Every six porters are allowed a light tent, and every three porters a three-legged cooking pot.

The head boy is allowed a small tent with fly, a blanket, and canteen.

The cook and gun bearers are provided with hunting 
knives, boots, and a cheap khaki suit; also with a tent and blankets.

The Askaris may be given a khaki suit and blanket; they bring their own rifles.

The cost of equipping the natives of a caravan, consisting of a headman, cook, cook's mate, two tent boys, two gun bearers, and thirty bearers is about 380 Rs., equivalent at the present rate of exchange to about $£ 41$.

The machilla. In the Portuguese colonies and Nyassaland travellers are frequently carried in large shaded hammocks known as machillas. A team of from 8 to 14 natives are employed, and they will cover up to 30 miles per diem. An able-bodied man naturally resents being carried about in this manner, but the machilla is very useful in case of sickness or accidents, or when there are ladies travelling.

\section{e. MOTOR TRANSPORT}

Of recent years the motor car has completely revolutionized veld travelling and is now used throughout the length and breadth of the sub-continent. Indeed, except in certain mountainous and swampy areas, in the sand desert of the Namib, the dune belts of the Kalahari and the forests of Angola and East Africa, motor transport may now be said to be practicable anywhere in southern and eastern Africa. Its remarkable spread has been partly due to the great improvements effected in motor cars of recent years but in the main to the astonishing achievements of motor 
transport in the campaigns of Southwest and East Africa, when cars successfully negotiated roads and tracks over which previously it would have been considered madness to attempt to take them.

The main result of this increased use of motors and the establishment of service stations all over the country has been an enormous reduction in the time taken for making journeys of any length. Thus a trip which formerly took weeks is now made comfortably in a couple of days, the net result being a great saving in every way.

The dependability of modern cars notwithstanding, the danger of breakdowns is too great to rely on a single car for main transport, and it is probable that in future the transport of all well equipped expeditions will consist - where it is possible to use motor cars of a tended wagon, drawn by oxen or donkeys, and a motor car for personal conveyance and for local journeys; or a motor lorry and motor car; the wagon or lorry, as the case may be, serving as a basis of operations and petrol depot. The great advantage of the former arrangement is that if the car gets stuck the draft animals are always a vailable to pull it out.

With regard to the class of car none has yet been found more suitable than the Ford. The engine is absolutely reliable, the clearance exceeds that of almost any other car, and repairs to body or wheels can generally be done on the spot by one device or another. The lightness of the car, moreover, renders it possible to work it out of difficulties in a way that is impossible with heavier cars.

A recent memorable exploring trip by a Ford car is 
that of Major Leipoldt, who motored all the way from Tsumeb, in Southwest Africa, to Humpata in Angola, a distance of over 1000 miles, mostly over trackless country, in an ordinary five-seater Ford, carrying eleven cases of petrol at the start.

The present price in South Africa of a Ford car, complete with spare wheel, is about $£ 235$. The running costs, including depreciation, work out for veld work at about $1 /$ per mile.

Even preferable to the ordinary Ford car for expeditions is a Ford 1 -ton lorry with box body, fitted with a hood and a worm drive in place of a differential. These lorries will carry a load of $2500 \mathrm{lbs}$. at a speed of 15 miles per hour over reasonably good roads and average about 15 miles to the gallon; running costs being about $1 / 6 \mathrm{~d}$. per mile. The back wheels should be fitted with oversize pneumatic cord tires, and the front wheels with ordinary pneumatics.

Such a lorry, in addition to $1000 \mathrm{lbs}$. of baggage and equipment, would easily carry 20 cases of petrol, which at only 12 miles to the gallon gives it a radius of operation of 960 miles, or say 1000 miles.

The inside can be converted into a comfortable sleeping compartment or living room, and by pulling a tarpaulin over the lorry, in the manner to be presently described, a veranda-like awning can be fixed up all round it.

The present cost of a lorry of this description, fitted with hood, oversize tires, etc., is $f 250$.

While the Ford car and lorry can be strongly recommended from personal experience, it is only fair to state that most strong American cars are suitable for 
veld work. Reos and Hupmobiles in particular have achieved a great reputation in South Africa. The former are largely employed in Southwest Africa and were exclusively used by the Anglo-Portuguese boundary commission, appointed some time ago to fix the northern boundary of Southwest Africa. Two sixcylinder Reo cars and a four-cylinder Reo speed wagon formed the transport. The total distance travelled was 716 miles - very largely over trackless country - and this was accomplished without a single mishap; mechanical troubles accounting for an aggregate delay of four hours during the whole journey.

European cars of ordinary make are, as a rule, useless for veld travel, as the engine is not sufficiently powerful in proportion to their great weight, with the result that they are incapable of forcing their way over bad roads, sand, etc. They, moreover, almost invariable have a very low clearance.

As regards the speed of travel by motor car this will of course depend upon the nature of the roads to be traversed, or upon the nature of the country where there are no roads. In trackless country about 20 miles per diem is all that can be reckoned upon, and often it is much less.

With regard to spares for the motor car these depend largely on the mechanical skill of the driver, but speaking generally as many spares as he is capable of using should be carried on the wagon or lorry, it being unnecessary to lumber up the car with them.

One or preferably two complete spare wheels, spare tubes, a so-called "5-minute" vulcanizer, a spare axle, spare spring blades, a few electric bulbs, a coil of strong 


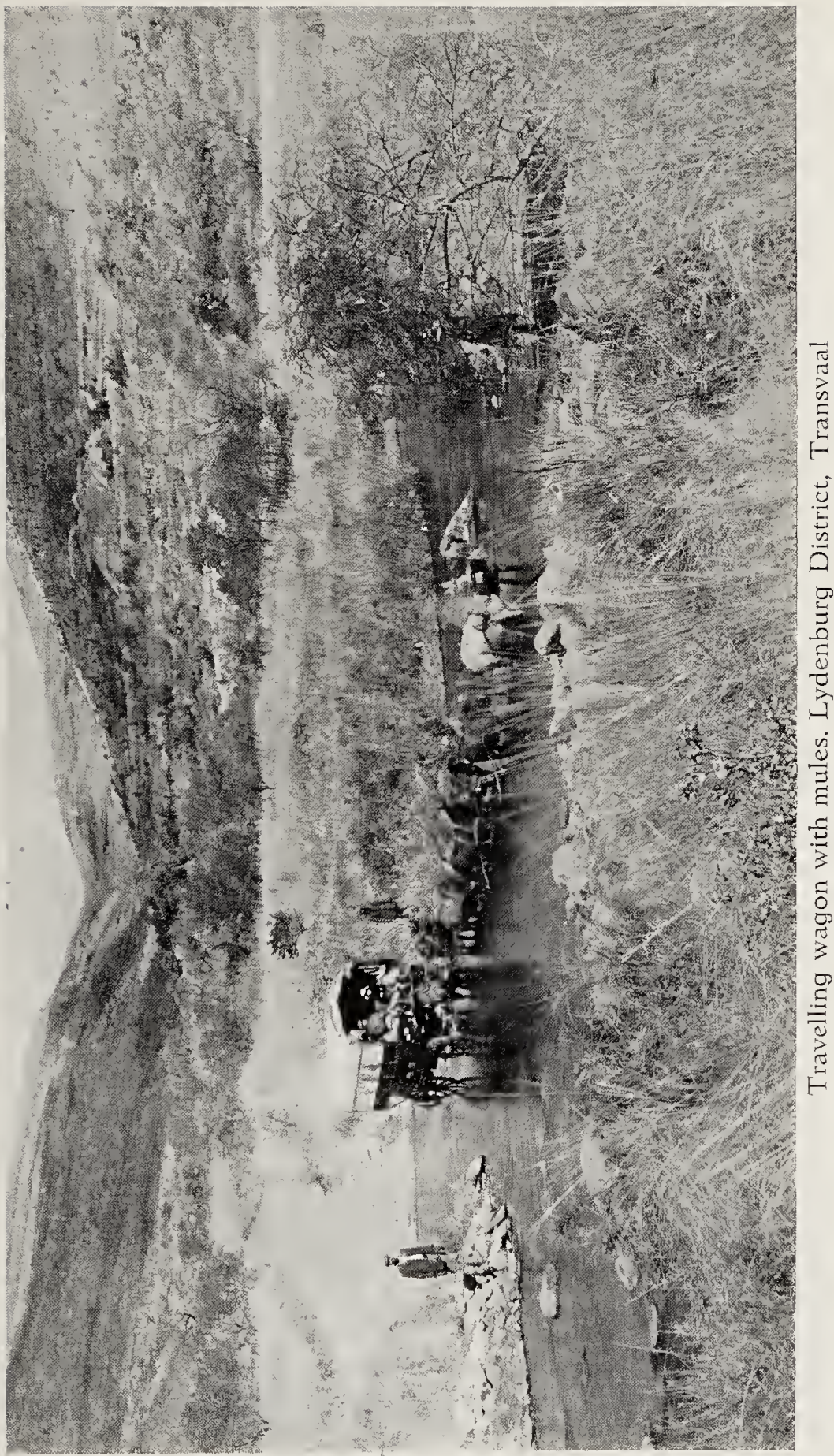



iron wire, the usual spanners, etc. are essentials, however, that no motorist can afford to be without.

The two main obstacles the motor car has to contend with are deep mud and sand. The former can to some extent be overcome by means of chains fixed to the back wheels or by putting on extra wheels behind. A very useful device for overcoming deep sand is to carry two long strips of stout wire netting which can be rolled up. If the car gets stuck in the sand these are pinned down in front of the hind wheels with ordinary iron tent pegs, enabling the wheels to get a grip and push the car forward. In long sandy stretches the process has of course to be repeated indefinitely.

Here is it recommended slightly to deflate the back tires.

Another useful device for getting stalled cars out of difficult places is the so-called "Poll-u-out" outfit, which consists of a pulley, 40 feet of steel cable, a small winding drum with gears inside engaging a small gear at the end of a ratchet crank, two seven-foot lengths of chain with hooks on each end, and three stakes specially designed for secure anchorage which are driven into the ground. The whole outfit weighs only 26 pounds and can be carried in the tool box. In travelling cross-country one picks up an astonishing number of large thorns, and as these are bound sooner or later to lead to punctures the tires should be carefully gone over at every long halt and thorns picked out.

Motor bicycles. Motor bicycles have also been greatly improved of recent years and will get almost anywhere. Their great disadvantage, even when fitted

Hin ts I 
with side cars, is their limited carrying capacity, which gives them a much smaller radius of operation than a Ford car. For carrying messages and despatches they are, however, unrivalled.

Cycles. An ordinary strong push bicycle is a very valuable adjunct to a wagon or motor lorry, particularly in the Portuguese colonies (Angola and Portuguese East Africa) where the natives are made to maintain excellent tracks, ideally suited to cycling, from village to village.

\section{f. WATER TRANSPORT}

Opportunities for long journeys by water are afforded only by the great South Central African rivers, viz: the Zambesi and its tributaries, the Okavango, and the Kwito, though considerable stretches of the lower Orange are also navigable.

On the Zambesi and the other Soutl Central African rivers named, the native dugout is in generai use and affords an easy and comfortable means of travel, provided that the services of an expert native paddler are available, as the propulsion of these awkward craft calls for considerable skill. The passenger sits in the bow and the paddler in the stern facing him, the baggage being piled up in the middle of the dugout. The rate of progression depends on the speed of the current and upon whether one is travelling upstream or downstream. I ownstream 25 to 30 miles per diem is generally averaged; travelling upstream it may be as little as 6 to 8 miles per diem. The paddler is paid about 1/ 
per diem but is generally better pleased at the end of a trip to get a blanket.

Excellent rafts capable of carrying very heavy loads such as wagons or motor cars can be made by linking together three or four dugouts in the orthodox manner.

On the upper Zambesi large, heavily built, flat-bottomed boats of European design are in common use by travellers. They are from $15 \mathrm{ft}$. to $20 \mathrm{ft}$. long and from $4 \mathrm{ft}$. to $6 \mathrm{ft}$. wide. The boats are paddled by a dozen or more natives who stand fore and aft, while the passenger sits in a deck chair under a shade of native matting erected amidships. One boat can carry two men and all their camp equipment. The distance covered in a day varies very much according to the state of the river. Against the stream when the river is full about 2 miles per hour or 16 miles per diem can be done. Downstream three or four times this rate may be relied upon.

It is customary to camp on shore at night, suitable landing and camping places being generally known to the natives. A light mosquito-proof cottage tent and the usual sleeping equipment should be carried.

It is necessary to take a certain amount of food, but fowls, eggs and sweet potatoes can always be obtained from the native villages along the river, either for cash or in exchange for goods. Edible fish can be caught in the river so that fishing tackle can be included in the outfit.

g. AIR TRAVEL.

The possibilities of the aeroplane for exploring and surveying remote and inacessible regions are only beginning vaguely to be realized. For making prelimina- 
ry reconnaisances to obtain some idea of the main features of an unknown tract of country and of the situation of the rivers, native villages, etc., within it, the aeroplane offers obvious advantages over other methods. It is, however, in actual mapping and surveying that it promises to find its widest and most useful field of application.

Aerial photographic surveying has of recent years made enormous progress, and it may safely be predicted that, in so far as those parts of Africa are concerned of which there are as yet noaccurate maps, this will prove by far the cheapest and most satisfactory method of making detailed surveys of areas covered by primary and secondary triangulation. A preliminary geodetic survey is of course necessary so as to have points to tie up with; the distance between "control" points, as they are termed, depending upon the accuracy required.

Surveys from the air will prove especially economical in the vast flat bush and scrub covered tracts that make up most of the central and northern Kalahari, Ovamboland, and northwestern and north-eastern Rhodesia, where ordinary surveying by theodolite and plane-table is very costly and laborious owing to the impossibility of getting long sights. Again for mapping an area such as the Ngami basin, with its labyrinth of waterways and great swamps, a survey from the air is not only likely to prove by far the cheapest and probably the most accurate but to involve the least risk to those engaged in the work, who in ordinary circumstances would be almost certain to contract malaria or black-water fever. 
Apart from ordinary mapping there is no reason whatsoever why preliminary botanical geological and even zoölogical surveys should not be made from the air. Altogether it looks as though the aeroplane were destined to be the most important factor in the era of African exploration now dawning.

Suitable landing places and petrol depots will of course have to be established, but that this does not. cffer insuperable difficulties is attested by the excellent work of the No. 3 Survey Party Royal Air Force, in connection with Sir Pierre Van Rijneveld's great Cairo-to-Cape flight in 1920. In desert and semi-desert country almost natural aerodromes are sometimes found ${ }^{1}$ ) requiring very little preparation beyond putting in large white circles which may be seen from the air and flags and small white patches to mark the boundaries. In bush country the trees and scrub have to be cut down and burnt and stumps remoxed, ant hills destroyed and the whole surface leveled and made as firm as possible, since soft ground is very bad for landing and taking (ff. All large trees near the boundaries are also cut down. Having done all this it is necessary to install permanently a small gang of natives for keeping down vegetation which would otherwise soon obscure the landing circle.

As to the cost of aerial surveys there is as yet very little to go upon. It is, however, very much less that that of ordinary surveys. Under the conditions obtaining in Egypt, which are very similar to those in the areas under consideration, it is estimated that the cost

1) Geographical Journal, September 1920. 
per square mile of map on a scale of $1: 2500$ would vary $\left.^{1}\right)$ from $\delta 5$ to $\approx 15$, whereas the cost of surveying the same ground by theodolite and plane-table varies from $£ 10$ to $f 1000$ per square mile.

\section{SELECTION AND PREPARATION OF CAMP SITES}

In selecting a site for a camp regard must be had to several important matters. In the firs tplace the camp should always be pitched on high ground having just enough slope to carry off water; never near the bank of a river or standing water and never to close to native villages or dense bush. Where there are shady trees about it is a great advantage to camp under one, but sight must not be lost of the fact that in the summer months trees often harbor venomous snakes.

The camp must of course be favorably situated with regard to water, fuel supply, and grazing when travelling with animals

It is always well during the winter months to safeguard the camp from grass fires by burning a fire ring, about 25 yards wide, round it, taking care that this is done under proper supervision so as not to set the surrounding veld on fire. When the rains begin it is very necessary to have a properly graded drainage trench dug all round the camp, and tents must moreover be ditched so as to prevent water from running under them.

When travelling with two wagons a very comforta-

1) Geographical Journal, June 1920. 
ble camp can be made by placing the wagons parallel to each other, about eight feet apart, and stretching a large tarpaulin over them; the tarpaulin being secured by large tent pegs and if necessary supported at the middle by means of a long pole. This provides a commodious living room and keeps the ground round the wagons dry. In rainy weather the cooking can be done under one corner of the tarpaulin. With a single wagon, motor lorry, or motor car an almost equally good awning can be made by stretching a tarpaulin over the wagon or lorry and attaching the ends on one side to three or four poles supported by guy ropes, or to trees if there are any about; the other end of the tarpaulin being tied on to the wheels of the vehicle.

For permanent camps some travellers favor lofty grass huts provided with mosquito-proof doors and windows. These are very cool and easily and cheaply erected in districts where natives skilled in this work are available. Native huts are, on the other hand, to be avoided as they are generally infested with vermin, and deserted huts often harbor snakes.

In malarious districts care should be taken not to leave old tins about near the camp as these are favorite breeding places for mosquitoes.

\section{CAMP EQUIPMENT}

TENTS

The most convenient pattern of tent is the "Cottage Tent," with fly and mosquito curtains not only for 
the ends, but on the walls so that they can be lowered when these are raised. Such curtains are not only necessary to keep out mosquitos but are an absolute godsend in places where house flies are abundant.

A very comfortable explorer's tent made by $\mathrm{V}$. S. Simpson \& Company of Pretoria, to accommodate two persons, measures $9 \mathrm{ft}$. $\times 8 \mathrm{ft}$. with $3 \mathrm{ft}$. walls; the total height being $7 \mathrm{ft} .6 \mathrm{in}$. It is provided with ordinary upright and joined cross poles and a large fly projecting beyond the tent on all sides, so that it can be used as a veranda. The ends and walls of the tent are lined with specially heavy fireproof mosquito curtains, and it is provided with a thick canvas floor cloth. Such a tent comfortably takes two stretchers and a small table. The cost depends upon the quality of the canvas used. With the best rot-proof canvas it is $f 24$, which includes a waterproof sack in which the tent travels when folded up.

A smaller $6 \mathrm{ft}$. $\times 8 \mathrm{ft}$. cottage tent costs f 21 .

Ordinary hemp guy ropes require constant attention as they stretch and contract with changes of the weather, and there are probably few travellers who have not had the unpleasant experience of getting up at night in pouring rain to slacken ropes or drive in pegs that have been pulled up owing to the contraction of the ropes.

All this trouble may be obviated by replacing the hemp ropes by woven ropes of flexible wire. This plan was adopted by Sir Milliam Morris when carrying out the geodetic survey of Transvaal and Orange River Colony and was found to answer admirably.

To allow for the expansion and contraction of the 
canvas of the tent the poles should be supported on pieces of wood or flat stones which can be removed when the canvas contracts and replaced as the tent dries.

Iron tent pegs are greatly to be preferred to wooden pegs, and a good supply of them should be laid in as they are also very useful for pinning down tarpaulins. The pegs should be carried in a special wooden box provided for the purpose.

Tents should never be packed up wet for travelling as this leads to the rapid decay of the canvas.

\section{TARPAULIN}

An absolutely essential article of equipment, no matter what form of transport be employed, is a good large waterproof tarpaulin, which can be used in a great variety of ways. The best tarpaulins are sold in Pretoria at 5/per square yard. They can be specially waterproofed by means of a patent wax preparation.

\section{CHAIRS AND TABLES}

Chairs and tables can be left tot he taste of the traveller. Many excellent patterns of camp tables are on the market and it is difficult especially to recommend any particular type. If, however, one is travelling with plenty of wagon accommodation and intends to be long in camp a strong military pattern barrack table, iron bound and with iron legs, is a great convenience over and above theordinary light camp tables. As regards chairs the ordinary folding canvas deck 
chair is hard to beat for comfort and convenience. In addition some small canvas stools should be provided.

PORTABLE BATH AND WASHSTAND

A combined folding canvas bath and washstand, obtainable at a price of about 35/, is a great comfort and convenience as it can also be used for washing clothes and for panning gravel or crushed rock on prospecting expeditions. A large sponge should be carried as it enables one to have a refreshing bath even when water is scarce.

\section{SLEEPING OUTFIT}

A folding camp stretcher should be carried when possible. In lieu of a stretcher a thick layer of cut grass makes an excellent mattress.

Blankets, sleeping rugs, pillows, etc. should always be contained in a waterproof valise of military pattern, as this keeps the bedding together and keeps it clean and dry.

The best pattern valise known to the writers ist he tent ralise, made by V.S. Simpson \& Company of Pretoria, as this opens up when necessary into a small mosquito-proof patrol tent, which is absolutely water-tight in the heaviest rain and at other times shelters one from the wind, sand, sun, and flies. Many of the officers of the Union forces used these throughout the campaigns in German Southwest and East Africa and found them absolutely satisfactory under the most trying conditions. The two photographs sufficiently 
explain the nature and manipulation of the valise. The cost complete with mattress, pillow, mosquito netting, and waterproof canvas bag and straps is $f 7$.

Even if supplied with a good valise the traveller is strongly recommended to take a stout waterproof ground sheet as these can be put to many uses in rainy weather.

It is most essential that all bedding should be aired in the hottest sun every day. Not only does this render it fresh and sweet but in many parts of the country especially in the damper regions - bedding becomes flyblown in the most unaccountable way when this simple precaution is not taken.

One or two large waterproof gunny sacks are invaluable in wet weather for carrying clothes and equipment.

Mosquito nets. In addition to his mosquito-proof tent or tent valise no traveller in the malarious districts of Africa can afford to be without a small bell-shaped mosquito net. These pack into a very small compass and can be suspended from the branch of a tree or from a stake driven into the ground. Properly tucked under one's blankets or valise they afford complete protection not only from mosquitoes but from snakes and other things that creep and crawl. Good stout mosquito netting should be used with not less than 20 meshes to the linear inch.

Umbrellas. Where survey work has to be carried out in the tropics during the hot period of the year a large 
surveyor's or garden umbrella, lined with green baize, is a great comfort.

Illumination. By far the most satisfactory illuminant for camp purposes is acetylene. The ordinary mining pattern lamps are the best as they are practically indestructible and fool-proof. A supply of spare burners, gaskets, and prickers should, however, betaken as natives are apt to lose these when cleaning the lamps. The ordinary small size mining hand lamp consumes about $\frac{1}{4} \mathrm{lb}$. of carbide in 8 hours. Special tins with air-tight lids should be carried to hold the carbide in use as it rapidly takes up moisture from the air and is very offensive.

Paraffin is awkward to carry, and lamps are far more likely to break. If paraffin is used, however, the "Hitchcock" mechanical draft lamp can strongly be recommended for reading, table illumination, etc.; and the ordinary "Hurricane" lantern for camp use.

An electric torch should if possible be included in the outfit, also several spare batteries; a torch being very useful in emergencies.

Fires for cooking and baking. Except in the Karroo and on the High Veld there is as a rule no difficulty in getting sufficient wood to kindle a fire. Even in the Namib one can generally find dry bushes or shrubs (Aevva sp; Sarcocaulon burmanmi) which burn readily. Where, however, no wood is available recourse has to be had to cow dung or camel dung, both excellent fuels though sometimes difficult to kindle. This difficulty may be overcome by sprinkling a little petrol over the 
dung before applying a match to it, when it quickly blazes up.

In South Africa the custom is always to support the cooking utensil either on stones or an iron trivet, or "drie voet," as it is termed. These can be made by any blacksmith and are a great convenience.

Cooking utensils and tableware. Many excellent compact canteens are now sold, made either of aluminium or other material. These are an immense convenience as, each article having its own definite place, the servants can observe when anything is missing and look for it at once. Apart from this they are an actual economy, as the articles bought separately cost more than the complete canteen. The yare of all sizess uitable to parties of any number.

Over and above the canteens some extras are, however, necessary. Thus, to drink tea or coffee out of a metal cup is very unsatisfactory, and it is worth while taking a number of the handleless glazed earthenware basins, called kommetjes, out of which the trek Boers usually drink. These are very cheap and carry without much breakage. If there are facilities for carrying them porcelain cups and glass tumblers should of course be taken.

An additional frying pan and some saucepans are an advantage, but the main cooking utensil and by far the most convenient one is the three-legged pot which is obtainable in every shop in Africa. There are two patterns - the round-bottomed one for ordinary cooking and the flat-bottomed, flat-topped one, known as the "Boer pot" for roasting and baking. 
Vacuum flasks. Vacuum flasks are an absolute godsend to the modern traveller as they keep food and drink either hot or cold as may be desired, and the comfort they give amply compensates for the space they occupy. They should if possible be carried in an upright position as the glass lining is apt to break at the neck if they are carried on the side.

\section{WATER AND FOOD}

Water. It should be taken as an absolute axiom that all water in Africa, with the exception of that of springs on mountains and the slopes of the Great Escarpment is polluted. Enteritis is endemic from one end oft he country to the other, though the inhabitants to an extent are immune to the disease.

In the circumstances strangers cannot be too careful about seeing that all water they consume is thoroughly boiled or sterilized before it is placed in the receptacles for storage. For boiling water a special utensil in the form of a large copper pot is sometimes carried and used for that purpose only. Sterilization by means of iodine is preferred by some to boiling. For this purpose Evans' sterilizing tablets should be carried. Full directions as to use are supplied with them. Each member of the party should be provided with a large feltcovered aluminium water flask.

Canvas water bags and water coolers are invaluable to the traveller, providing cool water in the hottest weather. On the other hand, however, they are probably the most dangerous articles of equipment unless properly looked after, as they collect filth and germs, 
and cases of enteric fever have frequently been traced to them. They should, therefore, be frequently washed out with boiling water or actually boiled. For camp use the sack type with an open top is generally used, but when travelling the closed type, where the only entry is the neck of a bottle sewn into the canvas or some similar divide, is necessary.

THE TSAMMA MELON

In parts of southern and central Kalahari the traveller has to rely for drink on the tsamma, a peculiar melon, while in so far as oxen, donkeys, and camels are concerned the tsamma affords both food and drink, and animals can subsist for months upon it.

There are two species of tsamma, namely, the ordinary (Citrullus vulgaris) and the bitter (Citrullus colocynthis). The latter, while practically identical in appearance with the former, is intensely bitter to the taste and cannot be used. The two varieties can be discriminated only by tasting. The usual method of extracting water from tsamma is to cut them in small pieces and boil them in a suitable vessel, skimming off solids and scum. Another way is to roast them in sand in a hole dug in the ground and then squeeze out the juice. Tsamma water is not very pleasant to the taste but quenches the thirst better than ordinary water. It can be used for all ordinary cooking purposes but makes abominable tea. When boiled the tsamma is also food for man.

\section{FOOD}

Game. Nowhere, speaking generally, can game be 
regarded as a reliable and constant form of food; sometimes weeks and months will be spent when nothing is seen. In the occupied territories the game laws also interfere, and there are closed seasons, so that game must now be regarded as entirely an auxiliary to the food supplies.

In the occupied territories foodstuffs can be bought from local stores, but these are usually so inferior that is is always advisable to order one's supplies from the nearest large town.

Though fowls, eggs, milk, and mealie meal can often be obtained from farms and native locations this can never be relied upon at the present time, and it is absolutely necessary for any expedition, even into the occupied districts of the country, to carry all the ordinary necessities with them, unless they are prepared to put up with lenten fare of the most inferior quality. In the native territories it is generally possible to obtain far more in the way of the foodstuffs from kraals and villages than in the more civilized areas.

With regard to the selection of supplies, every man should suit his own tastes, but it must be remembered that in camp life most men get an inordinate craving for jams, preserved fruit, and sugar. The ration allowance of these should be very much increased over the proportion in ordinary life. A large supply of dried fruit and prunes should also be taken as vegetables are, as a rule, only rarely obtainable. A very valuable substitute for ordinary tinned butter which is never very satisfactory is furnished by peanut butter which is now manufactured on a large scale in South Africa and can be purchased in all large towns. It is put up in 


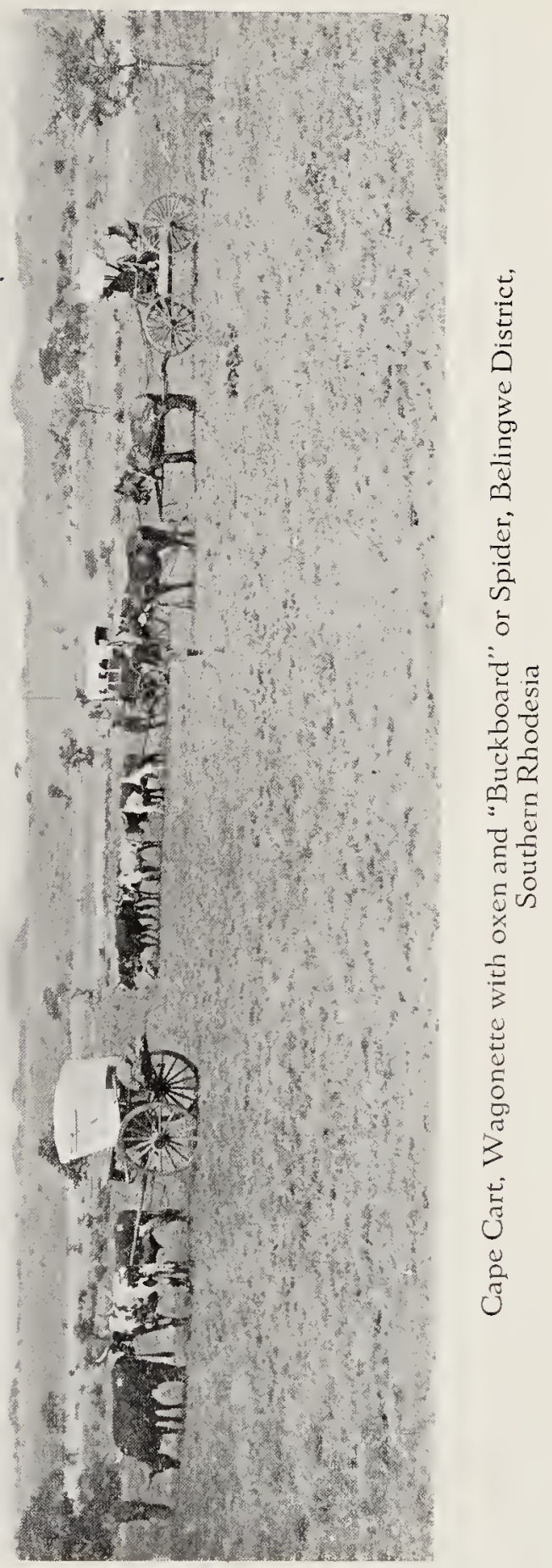



tins and jars and lasts indefinitely. In addition to being agreeable to the palate it is a very valuable food, rich in fats and vitamines. Peanut butter can also be used for frying and cooking in place of ordinary fat.

Certain articles such as sugar, salt, matches, soap, etc. are conveniently used as articles of petty barter, and service can usually be obtained for these from natives who refuse cash.

As regards the arrangement of food supplies a "mess box" should be provided in which all the articles of food in use can be kept, so that it is only necessary to draw on main supplies once a week or so.

A plentiful supply of small canvas bags and one or two large biscuit tins should also be taken in which to carry foodstuffs on minor expeditions.

Small covers made of mosquito netting with heavy beads sewn along the edges are invaluable for keeping flies out of milk and food. They should be regularly washed.

Bread baking. For bread baking the three-legged "Boer" pot, previously referred to, can most strongly be recommended. The baking process is very simple and may be briefly described as follows.

The dough, thoroughly kneeded with yeast, is put in to the pot, the inside of which has been smeared with dripping, and allowed to rise. When it has risen a wood fire is lit, hard heavy wood yielding good embers being the most suitable. When the fire has burned low a large shovelful of the embers is taken out and the remainer smoothed down. The pot is stood on the smoothed-down embers, and those in the shovel are spread out on its flat lid. After a short interval the fa- 
miliar smell of slightly burnt bread heralds the completion of the operation, when the pot is lifted off the embers and allowed to cool, the embers on the lid being swept off.

As a substitute for wood cow dung or camel-dung can be used, but they are of course not quite as satisfactory.

Portable meat safes. Very serviceable meat safes can be made by means of mosquito netting stretched over a light wooden framework. They are invaluable during the rainy season of the year when meat unprotected from flies goes bad in an astonishingly short space of time. A small bell-shaped mosquito net can, of course, also be used for this purpose.

\section{PERSONAL EQUIPIIENTT}

The thorns and grass seeds of Africa render tweeds and soft clothing quite impossible. By far the most serviceable and cheapest material is the ordinary khaki drill (not serge) of the British Army. Whether leggings or puttees are worn depends on the taste of the wearer; leggings are the most serviceable but are hot, and puttees are preferred by many.

Boots should be of the best possible quality but light. Heavy nailed, top or field boots are invariably discarded after experience has taught their disadvantages. Pliillips' patent rubber soles and soles cut from old motor car tires can be thoroughly recommended as they give a much better foothold on rocky ground than leather soles and do not like these become slippery as a result of walking through long grass. Boots should 
be brushed every evening and frequently rubbed over with "Dubbin" or saddle soap. This not only preserves them but greatly adds to one's comfort by keeping the leather soft and pliable. Travellers who have to spend long periods in malarious districts will find light mosquito boots, to slip on of an evening, a great comfort. A last and a small shoemaker's outfit should be included in the equipment of all large expeditions.

Slouch or double terai hats are by far the most convenient wear, but to many people a pith helmet gives such extra comfort as to compensate for its inconvenience.

Veils and goggles are unnecessary except in desert regions where they are a great comfort against glare, flies, and sand. Goggles made of chlorophyl glass can be recommended.

Underclothing is a necessity even in the hottest parts as it not only prevents chill but is a protection against the rays of the sun. A spine pad of thick red flannel, about 5 inches wide, sewn down the inside of the back of the shirt is a very great comfort in the tropical regions and is strongly recommended.

In areas where ticks are very bad it is advisable to wear long drawers completely closed in front.

The dust and grime of the veld soon blunt an ordinary razor beyond redemption by stropping. Safety razors and a good supply of blades are, therefore, recommended.

A pair of hair clippers, or safety hair cutter, should also be carried as it is advisable to keep the hair fairly closely cropped.

To those who burn or chafe much, a supply of talc 
powder and lypsyl will be found to justify their inclusion in the outfit; while a bottle of eau de cologne, in which a few drops of oil of wintergreen have been mixed, makes an extraordinary soothing lotion for chapping produced by desert winds. Another small bottle of eau de cologne with a larger proportion of oil of citronella is also very useful as an application prevent flies, mosquitoes and other insects settling on one for at least half an hour afterwards; often enabling the traveller to eat a meal in peace, which would otherwise be impossible.

One or more toothbrushes and a plentiful supply of tooth powder are of course essential.

As regards soap carbolic or coal tar are to be preferred by reason of their antiseptic properties.

\section{MEDICINES AND CARE OF THE PERSON}

A knowledge of first aid and bandaging is absolutely essential to anyone about to undertake an expedition in the wilds of Africa. Those who do not possess such knowledge are strongly recommended to take a short course in these subjects before starting out.

The subject of medicines is fully dealt with in standard books of travel and will therefore only briefly be touched upon. The traveller is advised above all things to carry an extravagant supply of Epsom salts, as these are not only useful for men and animals but are often sought for in barter by natives.

In addition to Epsom salts the medicine chest should contain the following:

Hypodermic syringe; surgical scissors and 
knife; Hemostatic forceps and tooth forceps; straight and curved surgical needles and silk; sheet wadding; cyanide gauze; boracic lint; bandages; oiled silk; fountain syringe; quinine; aspirin; calomel; morphine sulphate tabloids; opium pills; chlorodyne; Dover's powders; vegetable laxative pills; cascara pills; castor oil; corrosive sublimate tabloids; tincture of iodine; potassium permanganate; boric acid; zinc ointment; sulphur ointment; oil of cloves and antivenom toxin.

A safety razor blade disinfected by boiling makes an excellent substitute for a surgical knife.

Thorn scratches and veld sores. Apart from the more serious complaints that a traveller anywhere in Africa suffers from are thorn scratches and tick bites, which are apt to develop into very distressing veld sores. The cause of these sores is said to be an attenuated virus of septicaemia and they can be prevented only by immediate attention to every scratch or tick bite. The best form of treatment is the immediate application of tincture of iodine and a bandage. Where a thorn has to be extracted the needle or implement used should first be sterilized by passing it through the flame of a match. Where a sore has once formed or the slightest fester begun either on man or animal it is useless putting on any iodine, ointment, or dressing until the sore has first been thoroughly cleaned of all pus and dead skin. In the case of sores in the hand or foot this is best accomplished by sitting down and thoroughly soaking the limb in a basin of hot water in 
which a little mild antiseptic has been dissolved. When the wound is once thoroughly cleansed iodoform or any of the ordinary dressings or a hot water compress will be found quite effective.

With regard to antiseptics for dressing wounds either on men or animals most people are inclined to use these much too strong, so that the antiseptic destroys the healing tissues. This is especially the case with, corrosive sublimate tabloids, which should never be used stronger than directed on the bottle. It may be noted that the ordinary anti-friction grease of commerce is an excellent dressing for a wound in lieu of a better.

Ticks. Practically the whole of Africa is infested with ticks, and the traveller often finds himself covered with the nymphs. These are slightly larger than the English harvest bug and equally irritating, often producing a high temperature. They are so small and occur in such numbers that it is often quite impossible to pick them off, but a rub of grease or paraffin soon gets rid of them. The larger ticks are very apt to cause festering sores when pulled off after once having buried their heads in the flesh. They are best got rid of by dropping hot candle grease on them or smothering them in grease or some greasy salve, when they drop off by themselves.

Jigger Aleas. In East Africa "jigger fleas" (Dermatophilus (sarcopsylla) penetrans), which bury themselves under the toenails, are a peculiar curse. The natives are extraordinary skileful in extracting them, 
and every traveller in this region should allow his native servant to go over his feet regularly every day in search of them.

Snake bite. For snake bite potassium permanganate, a supply of anti-toxin serum, and a hypodermic syringe should be carried. Potassium permanganate if quickly applied — within five minutes -.- is an absolutely certain antidote, and a small supply should be carried by every member of the party. The most convenient way of carrying it is in a Lauder Brunton outfit, consisting of a small cylindrical case with a lancet at one end and a container for permanganate of potash crystals at the other. Three or four deep incisions are made over the site of the bite in the direction of the muscles, and crystals of permanganate vigorously rubbed in; or better still a solution of the permanganate is injected with a hypodermic syringe. A ligature is then applied between the wound and the heart and as much blood as possible squeezed or sucked out of the incisions. If the patient shows signs of collapse he should be given a strong dose of whisky or brandy or an injection of strychnine. In the case of complete colla pse strychnine should be injected and artificial respiration resorted to. Where the patient shows no distressing symptoms the ligature may be removed after half an hour. In any case it should not be allowed to remain on too long without being loosened.

The anti-toxin serum has the great advantage over permanganate of potash that it can be applied up to the time that the advanced symptoms of poisoning set in and even after this, though it is of course advan- 
tageous to apply it as soon as possible. It is injected hypodermically in doses of 10 c.c., being put up in small bottles of 25 c. c. Several of these ought to be included in the medical outfit. Two doses should be injected, preferably in different parts of the body. In the event of collapse the expedients previously referred to should be adopted.

It is advisable even when the patient has apparently recovered as the result of permanganate treatment to give him at least one injection of the serum. The latter is best kept at the base camp in a cool spot as it is apt to deteriorate.

Where neither permanganate nor serum is available a ligature should be applied, the site of the bite scarified, sucked, or cut and the services of a native doctor sought. Numerous instances of complete cures by native doctors are on record, and many old travellers and prospectors pin their faith on them in so far as snake bite is concerned.

Malaria and black-water fever. Malaria and blackwater fever have been the main deterrents to the exploration of the interior of Africa and, notwithstanding the great advances made in tropical hygiene, yearly claim many victims.

On the subject of malaria it is best to be guided by the advice given in standard medical works; the great point in this treatment being to administer quinine at the correct time, viz. just before the parasites break out of the red corpuscles of the blood. This is best determined by means of a temperature chart.

The prophylactic use of quinine - either bisul- 


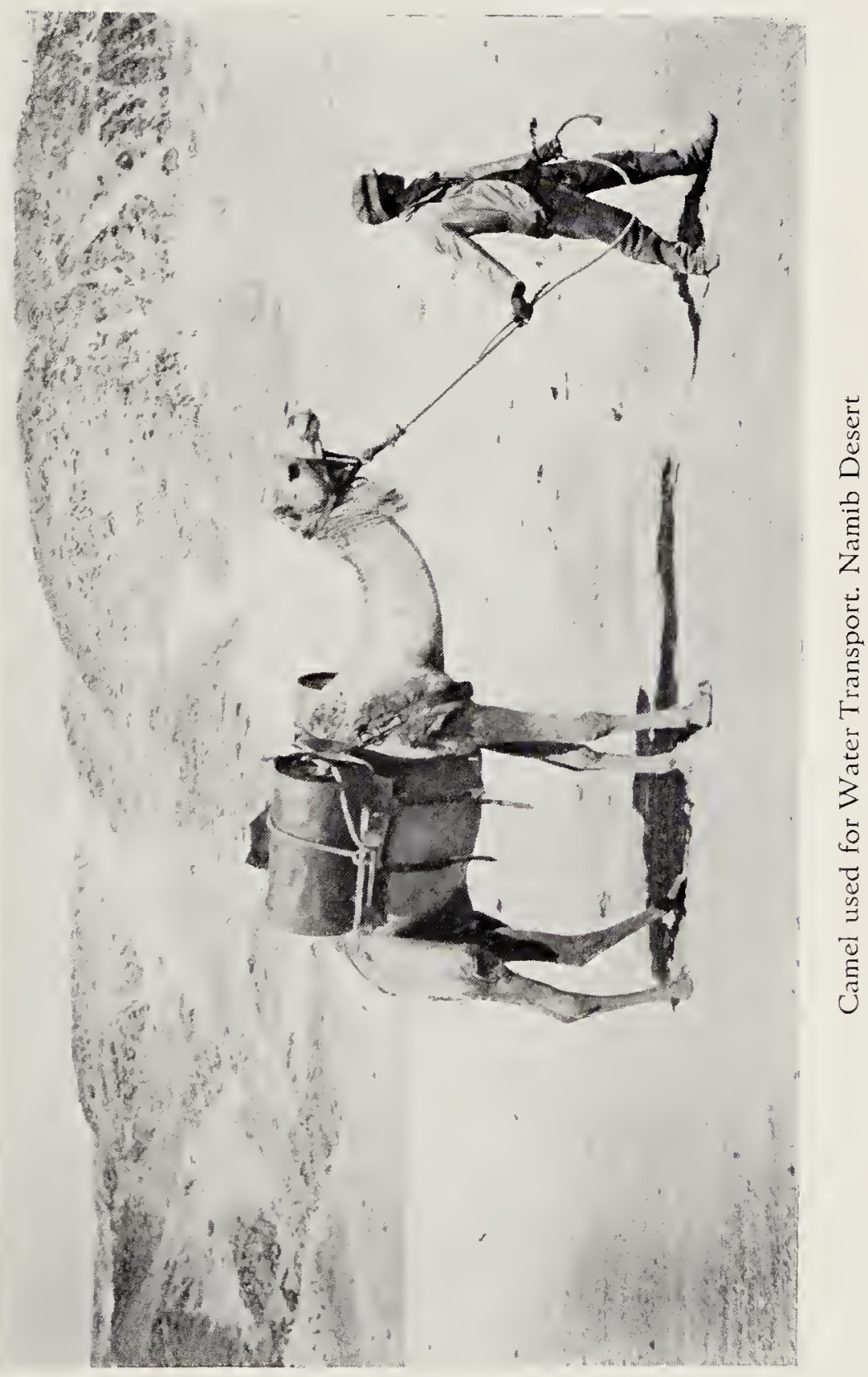



phate or bihydrochloride - cannot be too strongly recommended though it is a great mistake to take it too much. In the East African campaign excellent results were obtained by making the soldiers take a 5-grain (uncoated) tabloid on each of two consecutive days at intervals of three days, the process being repeated regularly.

Quinine is best taken with a little water just before meals. With regard to the more virulent disease known as black-water fever there is a theory that this is largely brought about in malarious patients by malnutrition owing to lack of vitamines in their food. One of the writers has been much impressed with this theory, for in a long experience of prospecting camps and pioneering in malarious districts he has always noticed that those men who live on tinned stuffs and alcohol are far more prone to contract this disease than those who take pains to obtain vegetables, milk, eggs, butter, and foods known to be rich in the vitamines. He would strongly impress on every man going into the wilderness that his chances of health depend more largely on the selection of a reasonable diet, than on anything else.

As regards the treatment of black-water fever the authors are happily in possession of some hitherto un published notes by the late Dr. P. A. Nightingale, an acknowledged authority on the subject with many years of practical experience in Rhodesia and the Far East. These may be summarized as follows:

1. The patient should be put to bed at once, warmly covered up with blankets and not allowed to get up on any account even for a single minute until the urine 
has been absolutely clear and normal for at least a week.

2. Heat should be applied over the kidney areas. This can be done by means of heated salt in a small bag, or hot sand or hot mealie meal porridge.

3. The patient should be made to drink unlimited quantities of fluids, especially boiled water, weak tea, or light kaffir beer. As long as there is free urination there is little or no danger.

4. No quinine or salts to be given, but the patient should be made to take a tablespoonful of Mixture No. 1 in water every two hours for the first twelve hours and then every four hours until the urine is clear; smaller doses being administered if it produces loosening of the bowels. Small doses of calomel, say $\frac{1}{4}$ grain, should be given two or three times on the first day, or, in place of calomel, vegetable laxative pills may be used.

5. When the water returns to normal give one tablespoonful thrice daily of Mixture No. 2 and begin to feed the patient gradually on a soft diet of milk pudding or biscuits and toast, etc., soaked in weak tea. Soups and Bovril are also good, and if the patient is depressed some whisky should be administered twice a day. Avoid overfeeding and giving meat or anything indigestible.

6. Unless hot water is available for a bath or sponging do not wash at all either during an attack or for a week after. Cold baths should not be taken for at least two months afterwards. Overexertion, chills, and drafts should be carefully avoided as they are liable to bring on a relapse which is always more difficult to treat than the original attack. 
7. As soon as the patient is convalescent he should be carried out of the district and taken to a nonmalarious area.

Quinine should not be taken for some weeks after black-water, but if fever continues take not more than $2^{1} / 2$ grains daily for some days. If it produces no discoloration of the urine take 5 grains daily but no more. If the urine gets dark in color again stop quinine at once, treat as for original attack of black-water and take no more quinine for two months.

Mixtures Nos. 1 and 2, referred to, are as follows:

No. 1.

Sodium bicarbonate. . . . 15 grains.

Solution perchloride of mercury . 1 dram (60 minims). Chloroform water. . . . . to 1 tablespoonful.

(Make 12 ounces).

No. 2.

Methyl arsenate of sodium . . . 1 grain.

Water .. . . . . to 1 tablespoonful.

(Make 8 ounces).

Solution perchloride of mercury . 1 dram (60 minims).

A supply of each should be included in the medicine chests of travellers in districts where black-water fever is prevalent.

With regard to the subject of alcohol there is much difference of opinion, but it appears to be firmly established that in unhealthy districts heavy drinkers and teetotalers are generally the first to fall victims to the climate. The writers do not attempt to account for this but merely place it on record in order to emphasize that the sensible temperate man has far less to 
fear from climatic influences than extremists or faddists.

In the absence of vegetables many white men in the backwoods of South Africa take to drinking native beer or even mahaeuw (fermented grain). It was formerly hard to account for this taste, but recent investigations at the Lister Institute show that these native beers and fermentation products from sprouted grain are very rich in vitamines, in fact more so than the lime juice of commerce, which evidently accounts for the development of this taste in Europeans deprived of ordinary vitamine-bearing food.

To those who are fond of tobacco that weed is an absolute necessity when in the wilderness; any harm it may do being amply compensated for by the feeling of comfort which it produces. For native employes also an ample supply of tobacco should be carried.

\section{V.III. ARMS, AMMUNITION, FIELD GLASSES, COMPASS, SIGNALS, GRASS FIRES, DOGS}

While it is very unlikely that the traveller will ever find it necessary to use arms against natives anywhere in the country under description, it is advisable in the more remote districts to carry a rifle, preferably one of simple pattern, designed for regulation 303 ammunition (sporting bullets), as this can be obtained from one end of the country to the other.

For sporting purposes and as a protection against wild animals and snakes a double-barreled 12-bore shotgun (left barrel slightly choked) and plenty of cartridges loaded with S. S. G. buckshot, No. 3 and 
No. 6, are essential. Cartridges should be packed in airtight tins or wrapped in waterproof packages. Waterproof covers or cases should be provided for the guns, and in wet weather these should be carefully cleaned and oiled every evening.

Fancy guns and rifles, though they may be most excellent weapons of extreme accuracy, are not advised as they are not "fool" proof, cannot easily be repaired, and the ammunition is probably unobtainable locally.

Unless actually attacked the traveller, if not a firstrate shot, is strongly urged to leave dangerous animals, such as lions, leopards, buffalos, and rhinos severely alone. There have been numerous fatalities through inexperienced persons being too venturesome in this respect. For defensive purposes against large carnivora a shotgun loaded with S. S. G. cartridges is a far more useful weapon in the hands of most people than a rifle. Pistols shooting special cartridges loaded with No. 4 shot are carried by some travellers as a protection against snakes.

With regard to knives, large hunting knives are only useful for show, and high quality knives of any description are not nearly as useful as the cheap soft steel variety, being far more liable to chip in the hard usages of the veld.

Field glasses, compass, etc. Good field glasses are a sine qua non, especially in bush country.

Every member of the party should also be made to carry a pocket compass to avoid the danger of being lost. Travellers should, however a,ccustom themselves 
to take their bearings by the sun and stars. There should also be a pre-arranged signal, such as two shots frred in rapid succession, in the event of anyone being bushed. Another effective signaling device is a column of smoke.

An excellent plan for fixing a line of march in bush country is to break down a small branch every ten or twenty paces in such a manner as to leave it suspended. This is simpler and more effective than blazing trees.

Grass fires. In some areas grass fires are a constant source of danger to the traveller during the dry season of the year. The only thing to do if threatened by one is to set fire to the grass in one's immediate neighborhood, burning off a large patch or better still a broad fire ring, and then to get into the middle of this. A bundle of dry grass makes an excellent torch, and, if there is any wind, an area or ring big enough to give complete immunity even to a large expedition can be burned off in a very short space of time.

Dogs. Dogs are a valuable adjunct to any expedition but have to be carefully looked after, particularly during the summer months when they are very liable to pick up ticks and develop biliary fever. A native should, therefore, be set aside to examine them for ticks at least once a day.

If a dog develops biliary fever - indicated by complete loss of appetite, lassitude and a temperature of from $103^{\circ}$ to $105^{\circ}$ - the only remedy is to inoculate at once with Tripan blue, a supply of which should be 
carried. The disease leaves the heart very weak and careful nursing is required during convalescence. If an abscess forms as a result of the inoculation this has to be lanced.

\section{MAPS}

Though a considerable part of the territories dealt with is covered by primary and secondary triangulation, they are on the whole very poorly off in the matter of accurate large-scale maps and particularly in the matter of topographical maps. It is generally the case, however, that the material available is not fully utilized. The traveller is therefore recommended to get into touch with the Surveyor General of the particular province in which his work lies in order to find out exactly what has been done in regard to the area to be examined.

It this way it is often possible to obtain tracings or blue prints of unpublished maps which are of the greatest assistance.

Maps are best carried in water-tight galvanized iron map cases provided with a good padlock.

For information in regard to magnetic declination, etc., Professor J. C. Beattie's "Report on the Magnetic Survey of South Africa," published by the Royal Society, should be consulted.

\section{INTERCOURSE WITH NATIVES}

The success or otherwise of an expedition will be found in no small measure to depend upon the travel- 
ler's ability to get on with his own natives and those with whom he may happen to come into contact. It is not merely a question of tact but of studying the workings of the native mind and allowing as far as possible for its idiosyncrasies. Only in this way can he hope to win their confidence and whole-hearted service.

It should be remembered above all things that the native of South and East Africa:

a. has a keen - almost an exaggerated - sense of justice; a promise once made, however trivial it may appear, should, therefore, always scrupulously be observed;

$b$. is an excellent judge of character and invariably respectful to those who command respect among their white subordinates, but inclined to take liberties with those who do not;

$c$. is, as a rule, a slave to superstition, including a belief in witchcraft;

$d$. is extraordinarily susceptible to suggestion. In endeavoring to obtain information anything of the nature of leading questions should, therefore, be avoided, as a native will always give the answer which he thinks is expected whether it is true or not.

It is also well to bear in mind that the native, speaking generally, is by no means a savage but is from his birth to his death subjected to very precise laws and customs which he has to observe if he wishes to be esteemed as a member of his tribe or clan. He should accordingly be treated as a man on a lower plane of civilization but not as a wholly inferior being.

The writers in a long experience of natives through- 



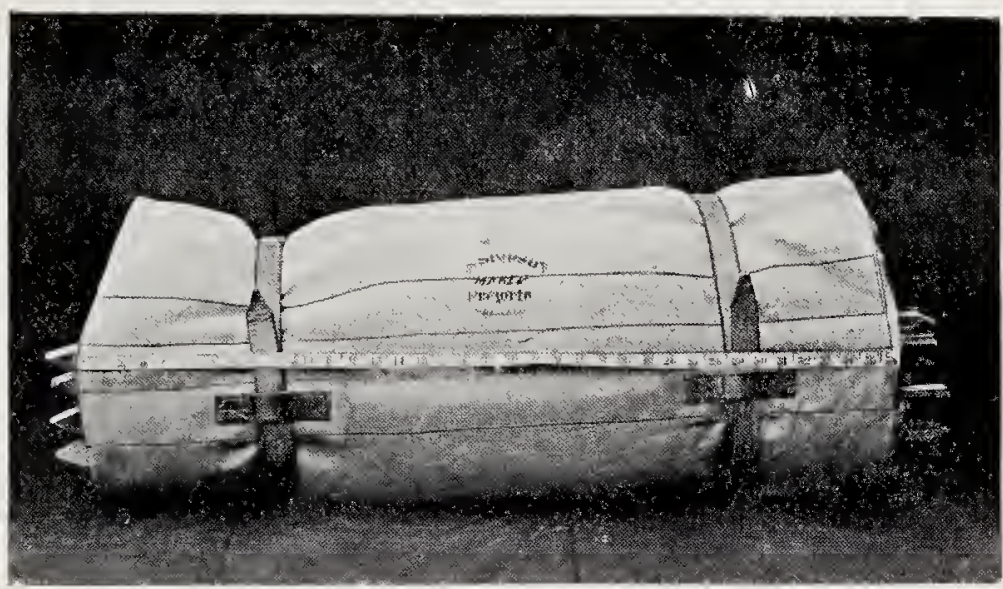

Tent-valise rolled up for travelling

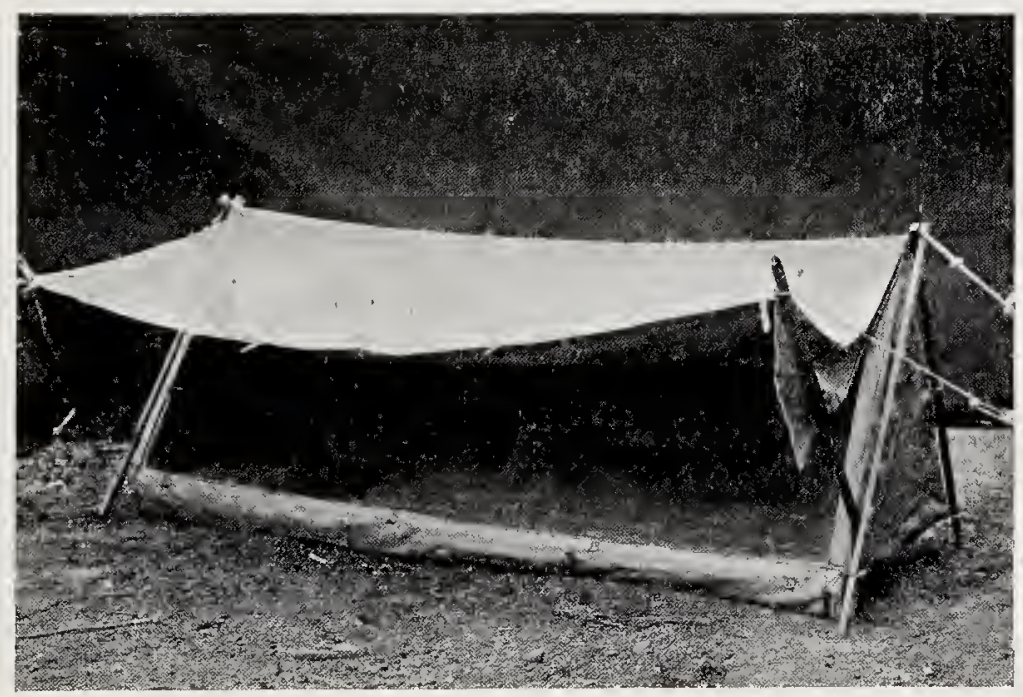

Tent-valise erected, the front is closed with mosquito netting 

out southern and eastern Africa have found them on the whole to be very honest and in their own way straightforward. Their veracity often leaves much to be desired, but then their standards in this respect are quite different from those of the European. Among most tribes, as a matter of fact, it is considered impolite to tell the truth if it should happen to be at all unpleasant to the person concerned. It is also quite useless to try and get a native to give evidence of an incriminating nature against one of his own clan.

The complex system of native relationship, due to polygamy and the link, of blood created by a common ancestry, is a fruitful source of confusion to Europeans and particularly to the newcomer. It is a difficult subject, and those desirous of studying it are recommended to read the chapters thereon in "The Ila-Speaking Peoples of Northern Rhodesia," by E. M. Smith and A. M. Dale (Macmillan \& Company Ltd., London 1920) and in "The Story of an African Tribe," by the Rev. H. A. Junod.

Articles of barter. For purposes of barter with natives it is very important to take the right class of articles and not to take too large a supply, as native tastes change as frequently and quite as arbitrarily as Paris fashions. One year a certain bead, blanket, or handkerchief will be the rage, and the women will give anything to obtain it. The next year the fashion will have altered, and they will hardly accept it as a gift. The following articles are, however, always in demand from one end of the country to the other, and when it is impossible to obtain service or goods for cash they 
can usually be obtained for one or the other of them:

Matches

Sugar

Salt

Soap

Epsom salts

Simple medicines, especially eye lotion.

Tobacco, preferably in plug form.

Common sweets.

Cheap scents (strong)

Needles

Thread

Iron and copper wire.

European shirts, boots, and clothing generally are also becoming more and more popular and will often be accepted in preference to anything else.

\section{LIST OF ILLUSTRATIONS}

Fig. 1. Full-tented ox wagon in the southern Kalahari.

"2. Travelling wagon in the Lydenburg District, Transvaal.

"3. Cape cart, wagonette with oxen, and "buckboard," or Spider, Belingwe District, southern Rhodesia.

„4. Camel used for water transport, Namib Desert.

"5. Tent valise rolled up for travelling.

"6. Tent valise erected; the front is closed with mosquito netting. 
HINTS TO EXPLORERS AND PROSPECTORS COVERING TRAVEL IN THE PHILIPPINES

$\mathrm{BY}$

WARREN D. SMITH, PH. D.

Head-Department of Geology, University of Oregon and Acting Chief, Division of Mines, Bureau of Science, Manila. 



\section{HINTS TO EXPLORERS AND PROSPECTORS COVERING TRAVEL IN THE PHILIPPINES}

BY

IVARREN D. SHITH

\section{INTRODUCTION}

This article has been prepared for the "Practical Hints to Scientific Travellers" edited by Prof. Dr. H. A. Brouwer of Delft, Holland, which is intended to furnish foreigners, and particularly white men, with reliable information concerning the best and easiest ways of carrying on general exploration in foreign countries. This chapter discusses conditions affecting travel in the Philippines.

The writer has spent ten years in geological and mining work in this archipelago, and the suggestions made herein are the results of his own experience supplemented by many valuable suggestions received from his many acquaintances among prospectors and mining men throughoutt he islands. To Messrs. Merrill, Banks, Haughwout, McGregor, Lee, and Schenck, his colleagues on the staff of the Bureau of Science ${ }^{1}$ ), Manila, who have given him valuable suggestions for this article, he also wishes to make acknowledgment.

1) The reader is referred to the 18 volumes of the Philippine Journ. of Science for scientific papers relating this particular field. 
The need for information of this character is easily recognized when it is recalled that one visitor to our shores, who posed as an engineer, insisted on wearing rubber boots in his field work (he had a serious time with infected feet). Another man, a high official of a past administration insisted on black wool Prince Alberts for outdoor functions of state at high noon! Some, either through pig-headedness or ignorance, have undergone untold suffering from diseases and others have been killed, all of which might have been avoided had they only known. Again, others, who have been forewarned, have discounted the advice given them and have come to a realization of their error after much loss of time and money. Even at this late day few people realize the economic importance of hygiene in this part of the tropical world.

In just a few words we shall summarize the most salient facts about the country, climate, andt he people of the Philippines as a setting for the suggestions to follow.

\section{THE COUNTRY OF THE PHILIPPINES}

The Philippine Archipelago lies some $800 \mathrm{~km}$. off the east coast of Asia, Manila the capital being 1100 $\mathrm{km}$. southeast of Hongkong. It comprises over 3000 islands, of which the largest, Luzon, has an area of $122,346 \mathrm{sq}$. km.

The islands are made up largely of Tertiary formations with some others of doubtful age. Volcanics and coral limestone are widely distributed, though there are considerable areas underlain by sedimentaries 
such as sandstone, shales, and conglomerates. Granitic rocks and schists are also well developed in certain parts.

The highest mountain is Apo in Mindanao, $2929 \mathrm{~m}$. The islands in general are mountainous and well forested, the dominant trees belonging largely to the Dipterocarp family, though many hundreds of sq. $\mathrm{km}$. are merely grass-covered. There are over 2500 species of trees known in the archipelago.

Situated as it is on the very edge of the great Asiatic continental horst and only $84.8 \mathrm{~km}$. west of the greatest known deep of all the oceans, the Philippine terrain is notstable, and earthquakes, only rarely destructive, are fairly common.

\section{THE CLIMATE OF THE PHILIPPINES}

For fuller treatment of this subject the reader is referred to the work ${ }^{1}$ ) of Rev. José Coronas S. J.

Philippine climate is tropical and insular. The climate is threefold in type.

The first type in the western part of the Archipelago, with two pronounced seasons; dry in winter and spring and wet in summer and fall.

2nd type - in the eastern portion — no pronounced dry season and with a pronounced rainy season in winter.

3rd type - in the central part - no pronounced maximum rain period and with a short dry season of from one to three months.

1) The Climate and Weather of the Philippines 1903-1918. Philippine Census A. D. 1918. Manila (1920). 
The first type is due to the southwest cyclonic winds. The second is caused by the northeast trade winds and cyclonic winds. The northeast trade wind is generally known as the northeast monsoon.

The third type prevails in the central portion of the archipelago including the Visayan Islands or where there is no pronounced cordillera.

The range of temperature in the lowlands is from $19^{\circ}$ to $32^{\circ} \mathrm{C}$. The mean annual temperature is $25^{\circ} \mathrm{C}$. In the highlands, like those of the north central portion of Luzon, the temperature is much like that of the temperate zone.

The mean annual precipitation in the archipelago is $159 \mathrm{~mm}$., and the greatest known rainfall for a 24-hour period was $879.8 \mathrm{~mm}$. at Baguio, North Central Luzon on July 14, 1911.

One unpleasant feature of Philippine weather is the prevalence, particularly in the summer months, of typhoons, which, however, are not as violent as the Gulf hurricanes of America. This class of storms usually sweeps across Luzon and rarely across .Iindanao from SE to NW. Snow and ice, more than a temporary film, even on the highest mountains are practically unknown. A thickness of $1 \mathrm{~cm}$, of ice is reported by Elmer 1). Merrill, Director of the Bureau of Science, from the western part of the Mountain Province, Luzon. 


\section{THE PEOPLE OF THE PHILIPPINES}

The population of the Philippines according to Beyer ${ }^{1}$ ) was in 1916 about nine and a half million persons, distributed as follows:

Christians . . . . . . . . . . . . . . 8,413,347

Mohammedans . . . . . . . . . 315,980

Pagans .. . . . . . . . . . . 618,637

Miscellaneous . . . . . . . . . . . 150,000

The Census of 1918 gives it as 10,350,730.

Christians . . . . . . . . . . . . 9,463,731

Non-Christians . . . . . . . . . . . . 886,999

There are some 43 ethnic groups recognized, of which the Visayans are the most numerous, the Tagalogs second, and the Ilocanos third. The Tagalogs are the most important politically. The Filipinos are predominantly of the Malay blend type with no slight admixture of Aryan (Spanish) and Mongol (Chinese). The three major ethnic groups are the Malay, the Indonesian, or Proto-Malay, and the Negrito.

These people are undoubtedly in the forefront of all the Malays and should be placed next to the Mongolians in the East in intelligence and progress. In some aspects of their political and religious life they are the most advanced people in the Far East. Physically they are somewhat inferior to the pcople of South China, whom they resemble to a certain degree.

With these few introductory remarks we shall proceed with the practical part of this paper. Having

1) Beyer, H. Otley. The Population of the Philippines, Philippine Education Co. (1916) Manila. 
just ended a few paragraphs relating to the people it is fitting that we first give some advice about travelling among the natives of the Archipelago.

The first and cardinal point to remember is that you are dealing with a people quite unlike any people in Europe or America and who must be treated otherwise than you are accustomed to deal with your own kind. If you hurry them you will only lose time and wear yourself out. Kindness will accomplish a great deal more than threats and curses. If you are not looking for trouble you are not liable to find it, but if you go around with a "chip on your shoulder" you are very likely to get repaid for your trouble. It is not necessary in travelling among the people to load one's self down with steel and lead. A good bolo is more useful than a revolver and then only as one would use a forester's axe in getting through undergrowth on mountain sides or along rivers.

\section{CLOTHING}

For field work the costume described below is eminently serviceable: flannel shirt (olive drab); long trousers, loose (in the seat and knees); canvas leggings or woolen puttees; army type of "hike" shoes with or without hobnails, or the rope-soled high canvas alparagata known as "Panays," made and sold locally; medium wool socks; and stiff felt hat with wide brim. The helmet or "topee" is not necessary and is often very impracticable. There is no danger from sunstroke in the Philippines. Many persons prefer the pith helmet as it keeps the head cooler than any other type of 
field hat. The writer nevertheless has not found it very desirable. There is not the same need for this type of hat as is the case in such countries as India. The main objection to a helmet is its size and shape, making an awkward head gear when going through undergrowth, and it is the best wind catcher in the world and looks unsightly when soiled.

The single-piece "B. V. D." or "union" underwear is the most practical underwear. It is needless to say that all clothing should be washed as often as practicable. Laundry work costs about 9 centavos $\left(4 \frac{1}{2} \mathrm{c}\right.$. U.S. money) a piece in this country. At night an abdominal woolen band should be worn to ward off intestinal catarrh from chilling.

\section{FOOD}

The principal articles of diet should be fresh, well cooked vegetables, fruits, rice, nuts, and bread. Meat is not necessary at all though often desirable to give a palatable change. The Philippines have the reputation of having the most delicious fruit, the mango, in the world, and the pili nut, though not so well known, is not excelled even by Brazil nuts. Of bananas there are more than 75 varieties, and they can be eaten either raw or cooked. Filipinos know how to cook rice to perfection, and this cereal should form the main article in the traveller's commissary. One word of special caution here - by no means should one economize in his food. Good, well cooked food in quantity is absolutely vital to good field work in this region.

There are many little tricks in the preparation of 
food which it is of value to know when living in out-ofthe-way places where cooking utensils are not easy to carry or buy, one of these is the cooking of rice in a bamboo joint. The Filipino stove, reduced to the simplest terms, consists of three stones placed near enough to each other to support a pot, and the natives are adept at building fires under difficult conditions, of which more in a later paragraph. A coconut shell makes an excellent bowl and a good spoon.

Canned or tinned goods are generally everywhere easy to get in the larger provincial towns, but these should be used as reserve only. Of canned goods available in the Philippines the writer would recommend the following:

Soups

Crackers

Preserves, jams, and jellies.

Bacon and tinned meats.

One should never take any of the crackers or cakes sent out from America in paper cartons. Everything of this kind should be in sealed tins. The traveller is cautioned not to delude himself with such makeshifts as Bouillon cubes, as these merely stimulate the appetite without affording much nourishment. It is not a good plan to stock up with many of the patent dried vegetables since fresh vegetables are generally available in quantity. Is is also a nuisance to have to soak desiccated food in water hours before using. Such foods are of no use when one is moving camp rapidly. One should always carry a reasonable supply of unsweetened chocolate in cake form as there is nothing in the way of food to equal this delicacy, which becomes 
a staple when it is impossible to cook a meal or when one feels fagged and needs quick, stimulating nourishment. It is particularly useful here in high mountain travel. A certain amount of sweet potatoes, sweet potato leaves, tomatoes, eggplant, bamboo sprouts, and other greens can be generally obtained and should be used. Lettuce should never be eaten uncooked as it is a common source of amoebae which cause dysentery.

In travelling through forests one has an almost constant supply of young rattan shoots which when roasted taste better than asparagus. Native guides may be relied upon to dig up food of a similar character which, while not always palatable, is generally worth trying.

Fish are abundant in Philippine waters and should be used whenever it is possible to get them. Oysters, clams, prawns, and squids are abundant, palatable, and safe except when taken from waters in the vicinity of large city sewage plants.

Two articles which the writer wishes especially to recommend are: tinned tomatoes, which can be eaten without further cooking and are the most refreshing thing for lunch on the trail, and "Bear Brand" milk which of all the tinned brands of milk seems the most satisfying as it is natural milk. As this brand is practically unknown to newly arrived Americans, the writer makes special mention of it here.

\section{WATER}

Throughout the Philippines one can generally drink from springs or from mountain streams with impunity 
except in western Mindanao and in Sulu where this must never be done, owing to the general pollution of all streams in Moroland. It is a religious custom among the Moros to defecate in running water, and they will not do otherwise. However, even in those parts where this custom does not prevail it is a wise thing to boil all drinking water or use tea. Further, it is well to boil all water in the lowlands because of carabao, etc., and to carry a small personal pint canteen.

There are several ways of quenching one's thirst in the Philippines, and one need never go thirsty even in the driest seasons. In the first place if a coconut grove is near by there is no finer drink than the milk of a fresh green cocoanut.

Next to this, water sufficient for an emergency can be secured from the rattan (bejuco) which trails and climbs everywhere in the jungle. The climbing bamboo also sometimes contains water between its joints, and lastly the pitcher plants (Nepenthes) have in the unopened leaves a somewhat tasteless sap, which will suffice in extreme cases. Of course many dry beds of streams afford water if one digs down a few feet.

Bottled aerated waters are generally available in the provincial towns.

\section{FIRE}

The natives of the Philippines have several ways of making fire without matches. The flint and steel is used by some of them (notably the Negritos), but perhaps the most interesting method is that which consists of splitting a section of very dry bamboointo halves. 
On the convex surface of one of these a V-shaped notch is made with a bolo, cutting through the wood; this notched section of bamboo is then placed flat on some stable surface convex side up, with a little dry tinder scraped out of the inside of the bamboo into a little pile just beneath the notch. With a sawing motion the edge of the other section is rasped back and forth in this notch. If the motion be rapid enough and the tinder very dry, fire will soon be forthcoming. The writer has made fire by this method but only with great exertion, while the native accomplished it with ease.

The Mangyans of Mindoro use a small bamboo tube with a plunger in it, by which they produce the necessary heat on the principle of the heating up of a bicycle pump. The writer has never seen the natives use the method of rapidly revolving one piece of wood in a hole in another, as is done in some countries.

Owing to the very generally wet condition of all firewood at certain seasons of the year it is a wise precaution for the traveller to provide himself with some kind of patent fire-lighter and a liberal supply of solid alcohol which comes in small tins; but, if bulky supplies cannot be carried, be at least sure to have matches in a waterproof container.

\section{SHELTER}

The native home, made of bamboo, nipa palm, and cogon or lalang grass (Imperata) is, for permanent camp, the cheapest and most comfortable kind of house for the tropics. Ordinarily when one is merely passing through a native town, he can always secure 
shelter with a Filipino family who, in their unequalled hospitality, will generally turn over the whole house to him, or at least offer him a generous corner, which during his stay is sacred to his uses and where his belongings will be safe, ummolested, and ready at hand when he needs them.

For rapid travelling in sparsely settled districts or where there is any doubt as to the attitude of the inhabitants, an oiled silk tent, with mosquito net, curtains, and windows, is the best. A tent of this material, made large enough to shelter four people, can be carried by one man. In one's personal kit should always be a waterproof cloth, to protect clothing, etc.

Along the principal government trails the Government maintains rest houses about thirty $\mathrm{km}$. apart at which one is furnished with bed blankets, and meals at an average charge of 1.50 (75 U. S. money) each.

The mosquito net is an absolutely indispensable adjunct of every traveller in the Philippine Islands. One should never, under any circumstances or in any place save at sea, lie down to sleep at night without having his net spread over him. This is the one and only way to avoid malaria and if followed means absolute freedom from this disease. If one finds that he cannot pitch his big net he should cover his head and shoulders with a small head net and then wrap himself up in a thin to medium woolen blanket. This article, of the type used by the U.S. Army, is quite as useful as the mosquito net and should always be carried. Nights are rare, outside of big cities, when a blanket is not very comfortable, and during the rain yor the cool dry season it is absolutely necessary. The bed- 


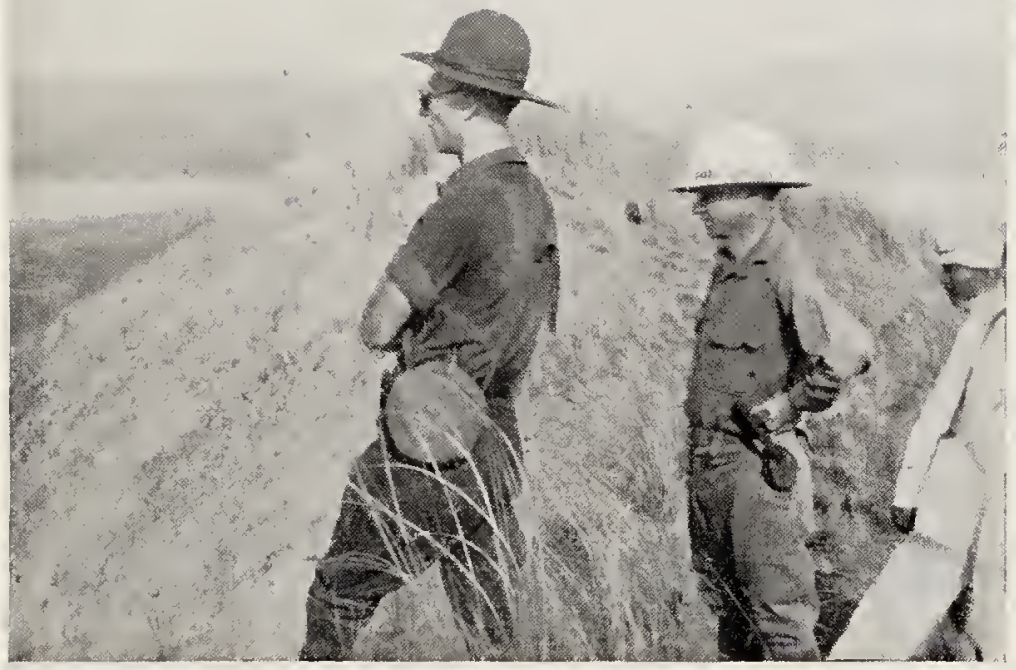

Approved costume of scientific fieldmen in the Philippines

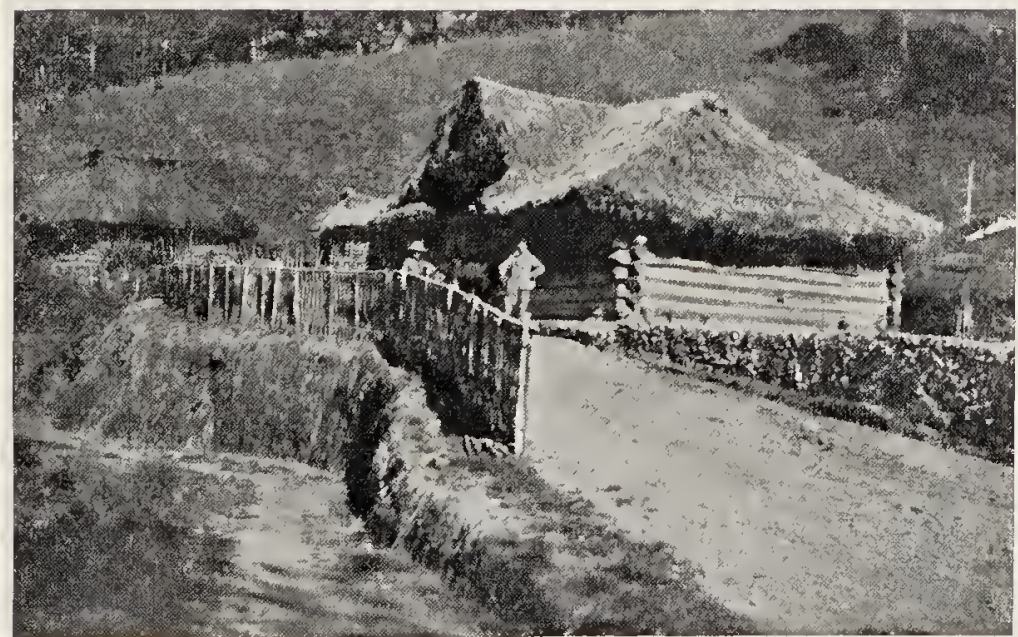

Government Resthouse on the Baguio-Suyoc Trail (Luzon) "30 kilometer house" 

ding, consisting of net, blanket, and perhaps a pillow, should be carefully wrapped in a rubber cloth or poncho, to protect it from moisture.

\section{TRANSPORTATION}

Every means of transportation from carabao, or water buffalo, to airplane is available in the Philippines.

There are about $1400 \mathrm{~km}$. of railroads in the Archipelago distributed as follows:

Luzon

Cebu, about

Panay

Mindoro, about

Negros, about
$1,235,377 \mathrm{~km}$.

95 " "
116
15

$100 "$ plantation lines.

The Philippines have today one of the most complete and up-to-date systems of macadam highways in the world and, with the exception of Java, are ahead, perhaps, of anything in the Far East. There are over 7000 licensed motor cars, trucks, and motor cycles in daily use in the islands. The roads of Baguio, the former summer capital, are not surpassed by any in the writer's knowledge. Of course when one gets into the heart of Mindanao or into parts of the Cordillera of Luzon he soon gets away even from horse trails and must depend upon horses, carabao and dugouts, and oftentimes his own ability to swim. In such regions as these one gets around very much as he does in the rest of the Malay region, made familiar long ago by such travellers as Wallace; but these methods need not be redescribed here. A bit of advice which may be useful 
in this connection is this: start early and stop early. Make camp before five o'clock in the afternoon because night falls suddenly in these low latitudes. Very often, especially in dry weather and in the time of the moon it will be found advantageous to travel at night. Over much of the country one is obliged to travel by foot or horseback, and then he usually employs native packers to carry his equipment, which should be put up in compact bundles weighing from 15 to 25 kilos depending upon the people among whom he is travelling. These cargadores, as they are called, are very sturdy and can travel long hours if well fed. The usual hire is from 1 to $1 \frac{1}{2}$ pesos each per day with food, which consists generally of rice and fish. One chupa (about $\frac{1}{3}$ liter) of rice per day per man; 1 can of salmon for 5 men for 1 meal or 1 can of sardines for 3 men is the usual ration. Two rules should be adhered to in using cargadores: never try to force your men to go beyond their district, exchange them for a new lot. Also never get too far ahead of your baggage. The carabao (water buffalo) is the best pack animal for the rainy season.

Occasionally, as in parts of the Mountain Province of Luzon, women are used for packing, but it is better to avoid such use, if possible.

From this naturally follows a word or two as to the best time for field work. It was the experience of the Spaniards, which the writer fully corroborates, that the best working time is from $7 \mathrm{a} . \mathrm{m}$. to $11.30 \mathrm{a} . \mathrm{m}$. and from 3 to 6.00 p.m. Some prefer to begin even earlier and work through till 1.00 and then lay off for the day. Under no circumstances, save in an emergency, should one work out of doors between 12 and 
3.00 p.m. It can be done, of course, but in time the ill effects will come upon one in the form of a general breakdown. Many of the writer's compatriots have not yet, after many years, learned this, and they are paying the penalty for it. When one becomes tired in the field as elsewhere he cannot do good work. Five or six hours is long enough for a white man to work outside, in the tropics.

\section{PROTECTION}

Firearms, except for hunting purposes, are generally unnecessary in the Philippines at the present time. A colleague of the writer was killed by natives some years ago, while he had two loaded revolvers strapped on him. If they set out to kill one they can very easily find ways to do it. Often the possession of a revolver merely incites them to murder.

A white man should never travel alone in the Philippines. If he has no white companion or assistant he should have a native with him. Most of these native companions, muchachos, or assistants are very helpful and faithful and will save one much trouble, especially in the matter of interpreting, finding guides, assisting in case of accidents, etc.

\section{HYGIENE}

So much has been written about this subject that the writer almost hesitates to add anything to it, but it is all so important that even at the risk of repetition he will make a few comments. First he wishes to insert a

Hints I 
short memorandum from his colleague Professor Frank G. Haughwout, parasitologist of the Bureau of Science of the Philippine Government, who has kindly summarized the essential features concerning important Philippine diseases.

"The traveller on a scientific mission to the Philippines runs relatively little risk of contracting the socalled tropical diseases provided he exercises a few simple precautions. Those which he must be on guard against are the various intestinal disorders and malaria. Fortunately, it is rather easy to avoid these.

"Before embarking for the tropics the traveller should be vaccinated against smallpox, typhoid fever, and the paratyphoid fevers. He may take the vaccination against cholera on arriving in Manila. In the latter case the procedure is similar to that in vaccination against the typhoids. The reaction, if any occurs, is exceedingly mild, and the immunity conferred lasts for several months. No person should embark on any expedition to the tropics before ascertaining his ability to tolerate quinine in the doses administered in the treatment of malaria. Most persons tolerate quinine well, but occasionally one is found who cannot take the drug even in small doses without experiencing a serious reaction. It is important to know if such an idiosyncrasy exists, for the inability to take quinine may lead to grave consequences should the traveller contract malaria in the field. Advice should also be sought from an experienced physician regarding the taking of prophylactic quinine in infected areas. The essential rôle played by the mosquito net scarcely needs emphasis here. 
"While it is comparatively easy to avoid contracting malaria, the avoidance of the dysenteries and other intestinal ailments is not so easy, for many more factors are involved. In some respects dirty hands constitute the greatest menace to the traveller in the tropics. All the intestinal diseases are contracted through the ingestion of the germs causing them. All represent the taking in of faecal matter, usually in minute quantities, excreted by other persons suffering from the same infections. Avoidance of these diseases consists in the avoidance of food and drink that may have become so contaminated, and the hands of food handlers are a prolific source of trouble. It should be remembered that even cooked food may afterwards be contaminated by food handlers or flies and become almost if not quite as grave a source of danger as uncooked food.

"Some one in the party should be delegated to see to the disposal of the bowel discharges of the members of the party. A place convenient to the camp should be so selected that it will not drain into any stream or body of water, or within the immediate boundaries of the camp, and every member of the party should be compelled to defecate into a pit at this point and immediately cover the faeces with earth as a protection against flies. Before the camp is abandoned, if circumstances admit, a hot fire should be maintained in the pit for at least half an hour.

"It should be remembered that practically every native of a tropical country harbors one or more intestinal parasites. Many of these are not a source of immediate infection, but others are dangerous as soon as 
they leave the intestinal tract. While much of the natural water in unsettled districts probably is safe, it should be recalled that in the Philippines typhoid fever is working into the native population and may be water-borne as may some types of bacillary dysentery. Therefore, as a general principle, all water used for drinking or cleaning of eating utensils should be boiled. Likewise, all green vegetables should be thoroughly cooked. Food handlers should be compelled to keep their hands out of the food. In the event of sickness, one member of the party should, if practicable, be delegated to look after the sick one, and he should not come in contact with the food of the remainder of the party. Venereal diseases are quite prevalent among the natives in the towns and cities and even in some of the wildest regions. The means for avoiding them are perfectly obvious."

The writer has been singularly free from sickness during his ten years in the Archipelago. He attributes this to his having followed a rational régime of living, consisting of the best food available, plenty of exercise, sufficient sleep, including a siesta at noon, and a temperate use of alcohol and tobacco. He cannot add much to what Professor Haughwout has said. Hewould like, however, to emphasize the need for exercise, which should always stop before one becomes too tired, of good food, of alcohol only as any other medicine and for its specific use as a stimulant, and of the rest in the middle of the day.

With reference to alcohol the writer wishes to state that he does not believe in prohibition as a principle, but he would urge temperance in the matter of alcohol 
especially in the tropics. The oft-heard advice that one should take whisky in order to get along out here is pure fallacy, and there is neither theoretical nor practical ground on which exponents of this idea can stand.

On the other hand the suppression of all appetites in this country is often very harmful. Of acute nostalgia, or exaggerated homesickness, we should say a few words. This may cause some people to smile, but here in the Philippines and doubtless in other tropical countries it is a very serious matter, and the victim of it must be brought out of it as soon as possible in order to avoid very regrettable consequences. It seems to be caused by the lack of congenial company, the inability to speak the language of the particular region in which one finds himself, and the reactions of the mind to the rather considerable physical readjustments which persons of the temperate regions must go through. Most persons experience no unusual discomforts while others are profoundly affected. Frequent change of scene and diversion, cold bathing, etc., are the best medicines.

The medicine kit whatever else it may contain should include the following:

1. Tincture of iodine (iodine swabs).

2. Quinine in 5 gr. capsules $(\mathrm{Q}$. bihydrochloride or sulphate).

3. Aspirin in 5 gr. tablets.

4. Soda mint tablets.

5. Calomel and salts.

6. Chlorodyne.

7. Bismuth in tablets.

8. Medicated gauze and cotton. 
9. Small surgical kit with scissors, scalpel, forceps, needles, and silk.

10. Flask of brandy, or aromatic spirits of ammonia. The ammonia is too volatile to keep its strength long.

11. 95 alcohol (ethyl).

It hardly requires emphasis, the danger from infection in this region; for this iodine is the best preventive.

\section{MISCELLANEOUS ITEMS}

\section{GAME}

The principal game in the Philippines consists of fish (sea and lake fish), wild carabao (water buffalo), tamarao, deer, wild hog, snipe, pigeons, wild chickens, and white parrots. On the island of Mindoro the wild water buffalo of the kind known as tamarao is not only unique but exciting to hunt. He is somewhat similar to the seladang of the Malay Peninsula in his fierceness. This animal is somewhat smaller than the carabao, with horns which point almost straight back. The tamarao is known nowhere else in the world.

Contrary to expectation there are few fish in the mountain streams as the torrential rainfalls of this region make it impossible for them to exist there. The deep-sea fishing in the waters about the islands is very fine sport, and an abundance of sea food is at all times available. 
REPTILES, ETC.

In many of the rivers of the Philippines there are crocodiles which have to be guarded against in bathing or fording. They have been known to attack men. While there are pythons, vipers, cobras, etc., in the Philippines the writer can say from his own experience in the jungle that they need be given little thought, as. they are rarely seen. First aid to bites must be given here as elsewhere, though more immediate attention is required. A cobra's bite in some instances may cause daeth in less than five minutes. In any event, the outcome usually is fatal unless serum is given promptly. Leeches in some parts of the Archipelago during the rainy season cause no little inconvenience. The stings of certain salt-water jelly fish give rise to painful and occasionally serious symptoms.

\section{PHOTOGRAPHY}

In the experience of the writer and his associates in the Bureau of Science the following rather definite conclusions and suggestions may be made for this region:

1. A $4 \times 5$ Graflex camera.

2. Use Seed's Non-halation plates. For contrast effects Wratten and Wainwright's panchromatic plates are recommended. Plates will keep without becoming moldy about a week, except in the dry season when they can be kept longer.

3. A portable developing outfit should be taken on long expeditions into the interior. Water-tight contain- 
ers should be provided for plates, films, and chemicals.

4. Practically the same time of exposure is required for pictures as in higher latitudes. If anything a somehat longer exposure is necessary. This is contrary to the general belief but is based upon both theoretical data and practical experience. Freer and Gibbs have shown that tropical sunlight is not materially different from any other sunlight.

5. Don't bring cameras using other than standard (for U.S.) size plates or films unless you are supplied with sufficient of your own because the local dealers carry only certain sizes and makes.

6. For the casual tourist a 3 A Special Eastman Kodak is good enough for all ordinary purposes, and films must be carefully protected against dampness. 





\section{Date Due}

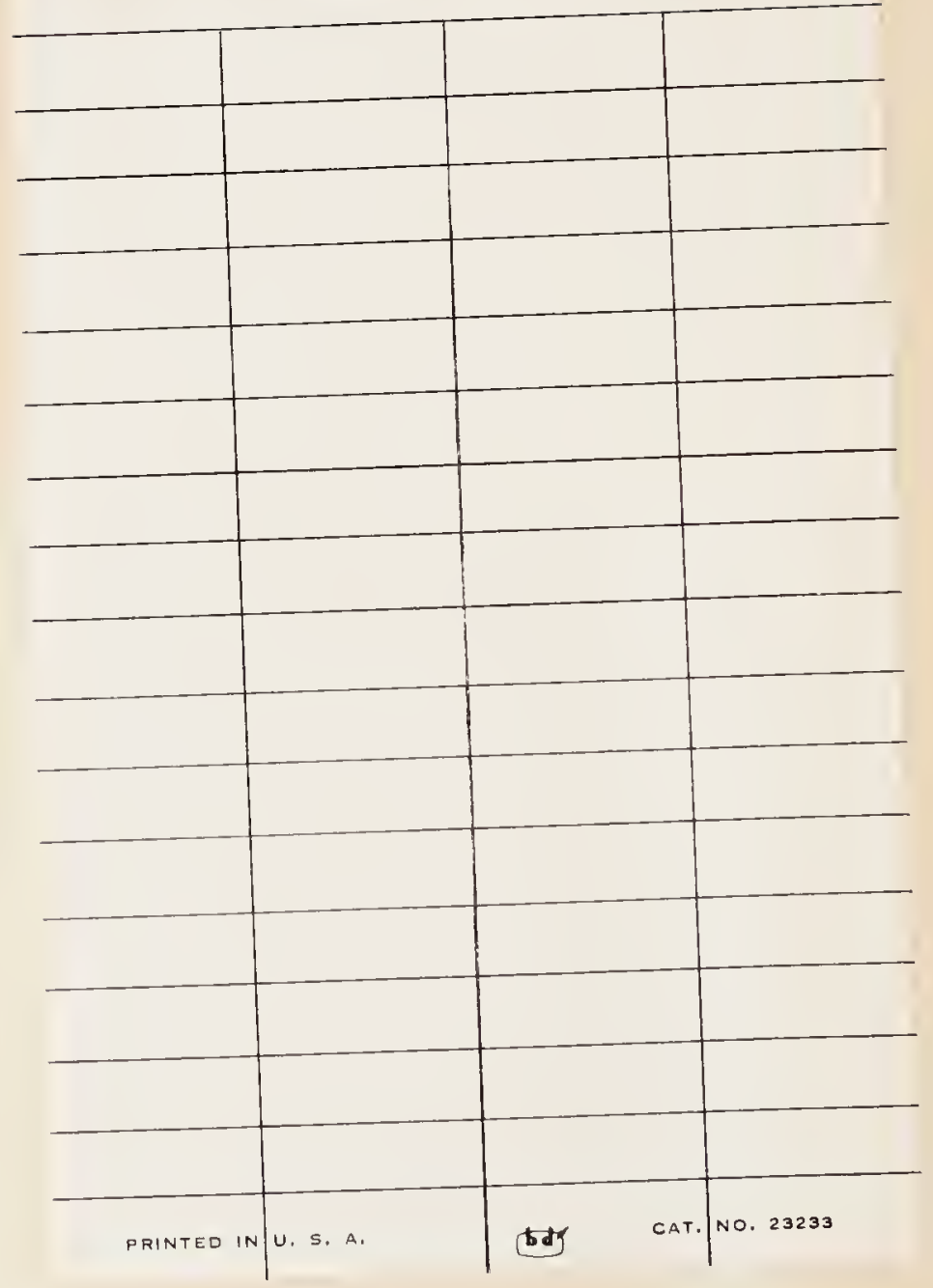




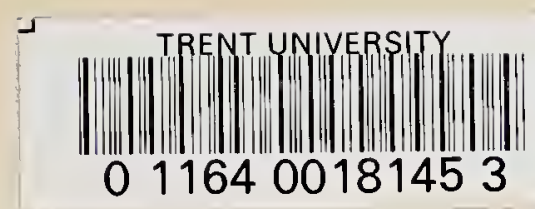

Q116 .B87 V.I

Brouwer, Hendrik Albertus.

Practical hints to scientific travellers.

003629 


\section{9 (5) $=0$}

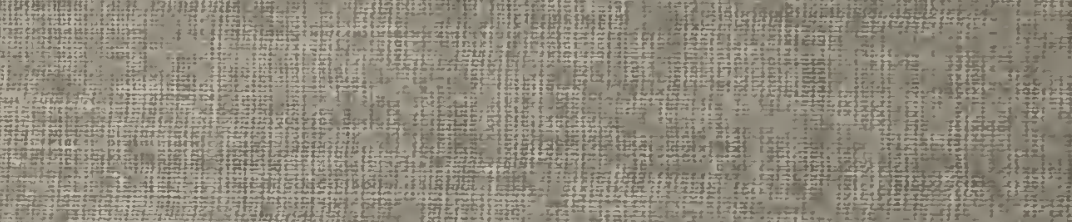

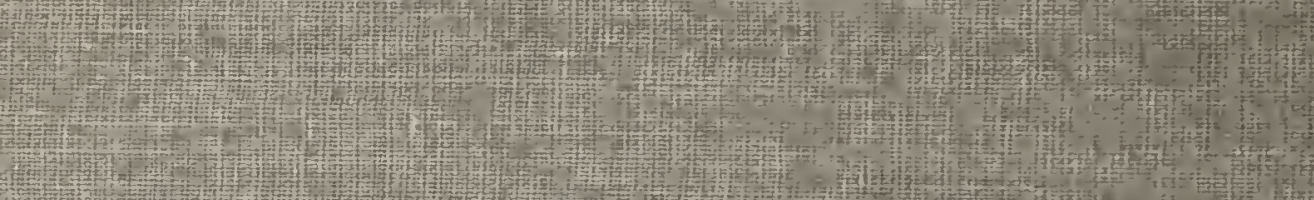

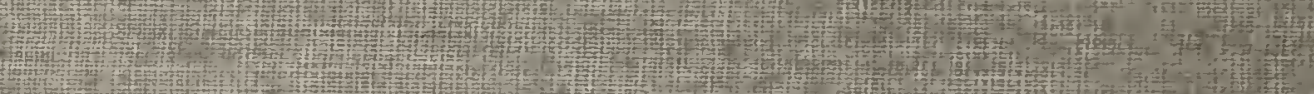

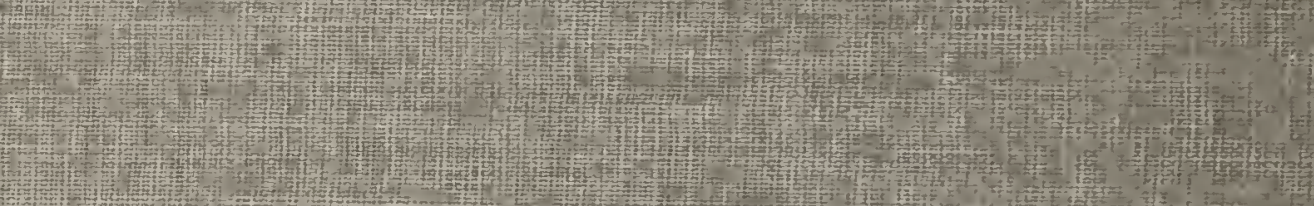
the

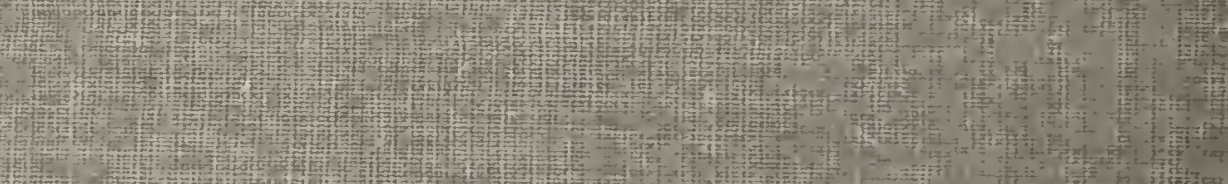

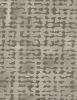

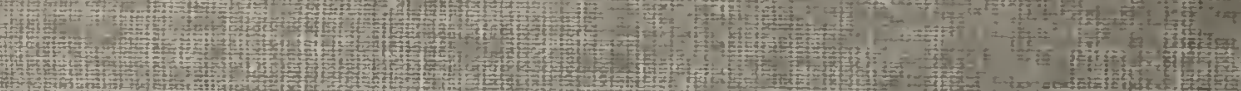

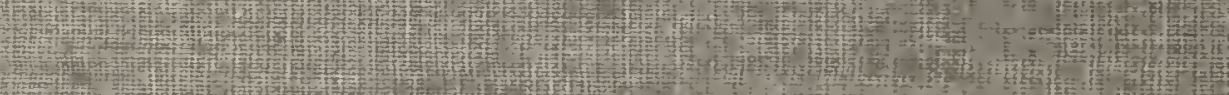
-

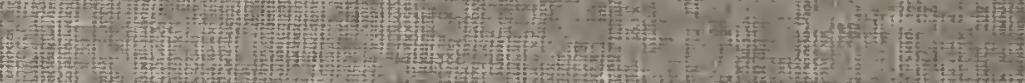
H. If

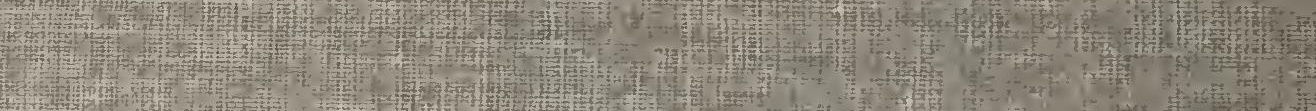
(20)

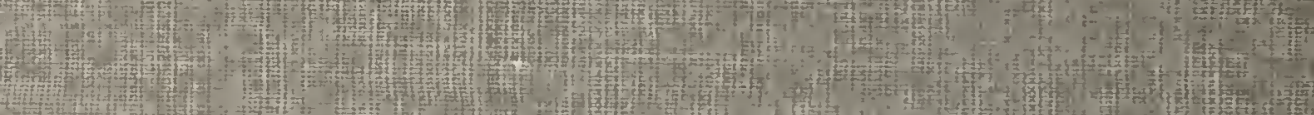

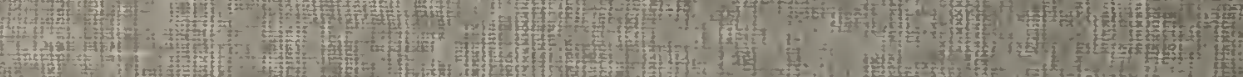

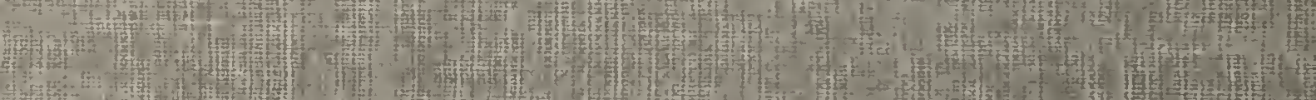

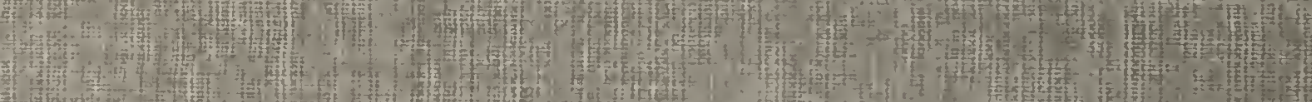

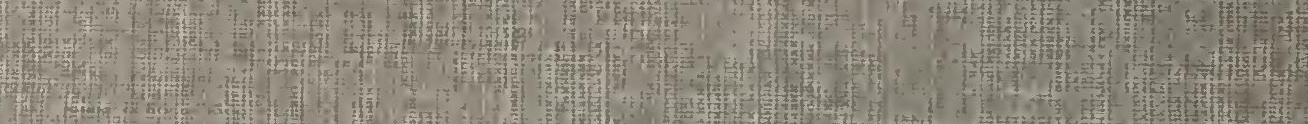

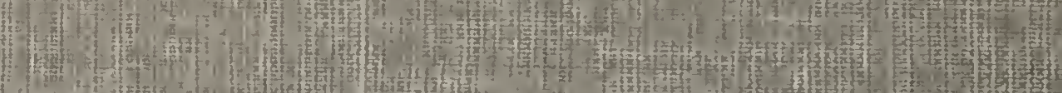
20.5. (15)

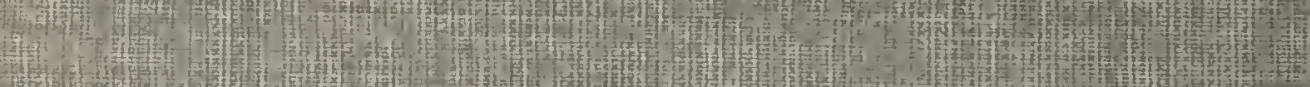

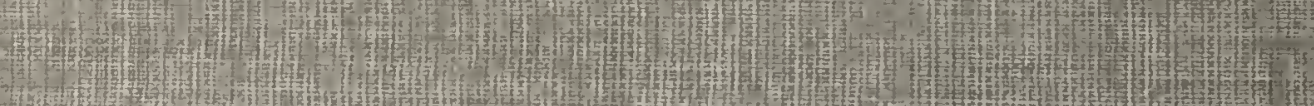
10.

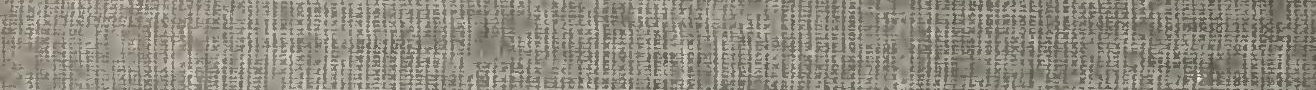
a 4.7. W

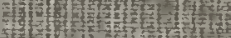

